\title{
Article \\ The Potency of Fungal-Fabricated Selenium Nanoparticles to Improve the Growth Performance of Helianthus annuus L. and Control of Cutworm Agrotis ipsilon
}

\author{
Mohamed A. Amin ${ }^{1}$, Mohamed A. Ismail ${ }^{1}$, Ali A. Badawy ${ }^{1, *}{ }^{\circledR 0}$, Mohamed A. Awad ${ }^{2}{ }^{-1}$, \\ Mohammed F. Hamza ${ }^{3,4}$ (D) Mohamed F. Awad ${ }^{5}$ (D) and Amr Fouda $1, *$ (D) \\ 1 Botany and Microbiology Department, Faculty of Science, Al-Azhar University, Nasr City, Cairo 11884, Egypt \\ mamin7780@azhar.edu.eg (M.A.A.); alazharbotany5617@gmail.com (M.A.I.) \\ 2 Department of Zoology and Entomology, Faculty of Science, Al-Azhar University, Nasr City, \\ Cairo 11884, Egypt; Mohamed_awad@azhar.edu.eg \\ 3 School of Nuclear Science and Technology, University of South China, Hengyang 421001, China; \\ m_fouda21@hotmail.com \\ 4 Nuclear Materials Authority, P.O. Box 530, El-Maadi, Cairo 11884, Egypt \\ 5 Department of Biology, College of Science, Taif University, P.O. Box 11099, Taif 21944, Saudi Arabia; \\ m.fadl@tu.edu.sa \\ * Correspondence: ali.abdalhalim@azhar.edu.eg (A.A.B.); amr_fh83@azhar.edu.eg (A.F.); \\ Tel.: +20-1006069161 (A.A.B.); +20-1113351244 (A.F.)
}

\section{check for} updates

Citation: Amin, M.A.; Ismail, M.A.; Badawy, A.A.; Awad, M.A.; Hamza, M.F.; Awad, M.F.; Fouda, A. The Potency of Fungal-Fabricated Selenium Nanoparticles to Improve the Growth Performance of Helianthus annuus L. and Control of Cutworm Agrotis ipsilon. Catalysts 2021, 11, 1551. https://doi.org/ $10.3390 /$ catal11121551

Academic Editor: Carlo Santoro

Received: 24 November 2021 Accepted: 14 December 2021 Published: 19 December 2021

Publisher's Note: MDPI stays neutral with regard to jurisdictional claims in published maps and institutional affiliations.

Copyright: (C) 2021 by the authors Licensee MDPI, Basel, Switzerland. This article is an open access article distributed under the terms and conditions of the Creative Commons Attribution (CC BY) license (https:// creativecommons.org/licenses/by/ $4.0 /)$.

\begin{abstract}
The application of green nanotechnology in agriculture has been receiving substantial attention, especially in the development of new nano-fertilizers and nano-insecticides. Herein, the metabolites secreted by the fungal strain Penicillium chrysogenum are used as a reducing agent for selenium ions to form selenium nanoparticles (Se-NPs). The synthesized Se-NPs were characterized using color change, UV-Vis spectroscopy, Fourier transform infrared (FT-IR) spectroscopy, transmission electron microscopy (TEM), energy dispersive X-ray (EDX), X-ray diffraction (XRD), and dynamic light scattering (DLS). The biomass filtrate of the fungal strain changed from colorless to a ruby red color after mixing with sodium selenite with a maximum surface plasmon resonance at $262 \mathrm{~nm}$. Data exhibits the successful formation of spherical, amorphous Se-NPs with sizes ranging between 3-15 nm and a weight percentage of 38.52\%. The efficacy of Se-NPs on the growth performance of sunflower (Helianthus annuus L.) and inhibition of cutworm Agrotis ipsilon was investigated. The field experiment revealed the potentiality of Se-NPs to enhance the growth parameters and carotenoid content in sunflower, especially at $20 \mathrm{ppm}$. The chlorophylls, carbohydrates, proteins, phenolic compounds, and free proline contents were markedly promoted in response to Se-NPs concentrations. The antioxidant enzymes (peroxidase, catalase, superoxide dismutase, and polyphenol oxidase) were significantly decreased compared with the control. Data analysis showed that the highest mortality for the 1st, 2nd, 3rd, 4th, and 5th instar larvae of Agrotis ipsilon was achieved at 25 ppm with percentages of $89.7 \pm 0.3,78.3 \pm 0.3,72.3 \pm 0.6,63.7 \pm 0.3$, and $68.7 \pm 0.3$ respectively after $72 \mathrm{~h}$.
\end{abstract}

Keywords: green synthesis; Penicillium chrysogenum; selenium nanoparticles; Helianthus annuus; cutworm Agrotis ipsilon

\section{Introduction}

The main challenge in the agriculture sector is to increase crop productivity and its products by safe approaches to cope with rapidly growing populations. Approximately one-third of crop productivity is lost due to microbial attacks, poor quality of soil, pest, and insect infestations, irrigation with contaminated water, and reducing the micro and macro-elements required for plant growth [1-3]. Therefore, new approaches are urgently 
required to overcome these problems. Nanotechnology has a promising approach to developing the agrotechnological system without negative impacts on the quality of foods. Nanotechnology is concerned with the production of novel compounds at a nanoscale range of 1-100 $\mathrm{nm}$ and can be integrated into various fields such as medicine, pharmaceuticals, chemistry, diagnosis, wastewater treatment, and the textile industry, to name a few $[4,5]$. Nanoparticles (NPs) are a final product of nanotechnology, and can be formed by chemical, physical, and biological methods. Due to the disadvantages of chemical and physical methods, such as involved toxic substances during synthesis, toxic by-products, harsh conditions needed for fabrications, and high processing cost, biological methods are preferred [6]. The metabolites secreted by various biological entities (bacteria, actinomycetes, fungi, yeast, and plants) are utilized for the green synthesis of metal and metal oxides NPs [7-9]. Among these NPs are $\mathrm{Ag}, \mathrm{Au}, \mathrm{Cu}, \mathrm{Se}, \mathrm{MgO}, \mathrm{ZnO}, \mathrm{CuO}, \mathrm{TiO}$, and $\mathrm{Fe}_{2} \mathrm{O}_{3}$, to name a few $[6,10]$.

Selenium (Se) is a fundamental element for humans, animals, and plants at a specific dose. This element has an effective role in normal plant functioning and hence protects them from various stresses [11]. Recently, selenium at the nanoscale (Se-NPs) has gained more attention, especially for plants due to their efficacy to alleviate several biotic and abiotic stressors such as heavy metals, salinity, drought, and heat, as well as their ability to inhibit the phytopathogenic microbes $[12,13]$. The positive or negative impacts of Se on plant growth are dependent on the concentration used. For example, at low concentration, Se can protect the fluidity and structure of chloroplast and plastid membrane, can reduce the metal genotoxicity, increase the cell integrity, decrease the leakage of electrolyte, enhance the photosynthetic process, delay senescence, enhance crop yield, and regulate the production of reactive oxygen species (ROS) in the plants $[14,15]$. In contrast, at high concentrations, Se can induce oxidative stress and ROS overproduction, damage plant cells, reduce the leaf area, inhibit seed formation, decrease crop yield, and deform the plant cell structure [14,16].

Helianthus annuus L. or sunflower is both useful and beautiful as named by farmers. Sunflower belongs to the Asteraceae family (Compositae), has a flowering head (capitulum) surrounded by outer yellow florets to attract the pollinators. It also contains inner florets as a brownish disc that are fertile and arranged in a spiral whorl from the center to the head [17]. The sunflower plant has a high economic value, it can be cultivated as an oilseed crop, their seed can be eaten by humans, animals, and birds. Moreover, sunflower seeds are a premium source of proteins, unsaturated fats, vitamins such as B1, B5, and B6, copper, phosphorus, iron, manganese, folic acid, zinc, tannins, alkaloids, oleic acid, and amino acids [17,18]. Medicinally, the seeds of sunflower are used to calm the muscles, nerves, blood vessels, have an anti-inflammatory effect, are anti-asthmatic, have antioxidant activity, treatment of high and lower pressure, and reduce heart disease risk [18,19].

The cutworm Agrotis ipsilon is considered the major destructive insect that can attack different crops, weeds, and vegetables such as clover, cotton, soybean, corn, tomatoes, tobacco, lettuce, eggplant, turnip, broccoli, and potatoes worldwide [20]. The larva of this insect attacks the plants by cutting the stem below or above the soil, living and hiding inside the soil holes during the day. Based on damages caused by the Agrotis ipsilon insect, the conventional methods including chemicals and synthetic insecticides are still used to control larvae growth. These conventional methods have negative impacts on humans, animals, and eco-system. Hence, it is urgent to establish a new method that is low cost, effective and environmentally friendly for insect control.

Therefore, the current study aims to develop a rapid, effective, and environmentally friendly approach used for the enhancement of the growth performance of the plant and prevent crop damage caused by insects. To achieve this goal, the metabolites secreted by the fungal strain Penicillium chrysogenum F9 were used as a biocatalyst for the formation and stabilization of Se-NPs. The biosynthesized Se-NPs were characterized by a color change of fungal biomass filtrate, UV-Vis spectroscopy, Fourier transform infrared (FT-IR) spectroscopy, transmission electron microscopy (TEM), energy dispersive $\mathrm{X}$-ray (EDX), $\mathrm{X}$-ray diffraction (XRD), and dynamic light scattering (DLS) analyses. Moreover, the efficacy 
of different Se-NPs concentrations on the growth performance of sunflower and inhibit the growth of different Agrotis ipsilon instar larvae was investigated.

\section{Results and Discussion}

\subsection{Biosynthesis of Se-NPs}

The green synthesis of metal and metal oxide NPs is achieved due to the activity of metabolites secreted by various biological entities such as plants, algae, fungi, bacteria, and actinomycetes to reduce, cap, and stabilize metal ions [21]. In the current study, the metabolites involved in biomass filtrate of the fungal strain Penicillium chrysogenum F9 have the efficacy to reduce Se ions and form Se-NPs. In our recent study, this fungal strain was used to fabricate silver nanoparticles (Ag-NPs) to control the growth of various Candida strains [22]. P. chrysogenum has the efficacy to produce a wide range of secondary metabolites that act a biocatalyst to reduce and stabilize NPs. Among these metabolites, are penitric acid, chrysogine, chrysogenin, fungisporin, roquefortines, and different enzymes and proteins $[23,24]$. The reduction, capping, and stabilizing Se-NPs can be attributed to these wide secondary metabolites range.

The successful Se-NPs formation was monitored by the color change of fungal biomass after adding metal precursor $\left(\mathrm{Na}_{2} \mathrm{SeO}_{3}\right)$ from colorless to ruby red color (Figure 1A). Compatible with our study, Joshi and coauthor reported that the efficacy of the fungal strain to reduce Se ion and form Se-NPs is due to their various proteins and enzymes secreted extracellularly [25]. The shifting of color because of the surface plasmon resonance (SPR) as reported previously [26].

\subsection{Characterization of Selenium Nanoparticles}

\subsubsection{UV-Vis Spectroscopy}

Besides color change, the synthesis of Se-NPs was proved by measuring the maximum SPR using UV-vis spectroscopy at a wavelength between 200 to $500 \mathrm{~nm}$. As shown in Figure 1A, the highest SPR for Se-NPs fabricated by P. chrysogenum was noticed as a single absorption peak at $262 \mathrm{~nm}$. The obtained data are compatible with those recorded by Abbas and Abou Baker [27], who reported that the highest SPR for Se-NPs fabricated by Fusarium semitectum was observed at $262 \mathrm{~nm}$. Moreover, the Se-NPs synthesized through harnessing metabolite secreted by Penicillium corylophilum strain As-1 showed a single SPR peak at a wavelength of $275 \mathrm{~nm}$ [28]. The bacterial (Bacillus megaterium) and fungal (Aspergillus terrus) mediated green synthesis of Se-NPs showed maximum SPR peak at $245 \mathrm{~nm}$ and $261 \mathrm{~nm}$ respectively $[29,30]$. The shape of synthesized Se-NPs can be predicted based on the SPR peak, the spherical shape is represented by a single SPR peak, while more than one SPR peak is referred to as anisotropic compounds [31,32].

\subsubsection{Fourier Transform Infrared (FT-IR) Spectroscopy}

The various functional groups that exist in the fungal biomass filtrate and are corresponding to the reduction of Se ion to form Se-NPs as well as capping and stabilizing of as-formed NPs were investigated using FT-IR analysis. The FT-IR for cell-free filtrate of P. chrysogenum F9 was previously analyzed [22] and showed four intense peaks observed at $3320 \mathrm{~cm}^{-1}, 2550 \mathrm{~cm}^{-1}, 1635 \mathrm{~cm}^{-1}$, and $666 \mathrm{~cm}^{-1}$. These peaks are shifted in the new chart of Se-NPs (Figure 1B). As seen, there are six peaks in the FT-IR chart represented by $520 \mathrm{~cm}^{-1}, 1025 \mathrm{~cm}^{-1}, 1380 \mathrm{~cm}^{-1}, 1543 \mathrm{~cm}^{-1}, 1635 \mathrm{~cm}^{-1}$, and $2990 \mathrm{~cm}^{-1}$. The peak observed at $3320 \mathrm{~cm}^{-1}$ in fungal biomass filtrate was shifted to $2990 \mathrm{~cm}^{-1}$ which is related to the stretching $\mathrm{N}-\mathrm{H}$ group of the secondary amide for fungal protein [33]. This indicates the role of $\mathrm{N}-\mathrm{H}$ containing proteins in the reduction of Se ions and forming Se-NPs. Moreover, the peak at $1638 \mathrm{~cm}^{-1}$ is referred to different moieties of peptide linkages and polysaccharide rings such as $\mathrm{C}=\mathrm{N}, \mathrm{C}=\mathrm{O}$, and $\mathrm{C}=\mathrm{C}$, while the peak at $1543 \mathrm{~cm}^{-1}$ for $\mathrm{NH}$ bend for primary and secondary amines [34,35]. The medium peak at $1380 \mathrm{~cm}^{-1}$ corresponds to $\mathrm{C}-\mathrm{H}$ bending of aldehyde, whereas the peak at $1025 \mathrm{~cm}^{-1}$ is attributed to C-N (primary amine stretching), skeletal C-C vibration, $\mathrm{C}-\mathrm{O}$ (stretching) of a primary alcohol, C-N-C 
stretching bands, and C-O-C stretch [36,37]. The new peak at $520 \mathrm{~cm}^{-1}$ was observed in FT-IR for Se-NPs and it refers to successful conjugation between the OH group and Se-NPs as Se-O [28] overlapped with C-H out of plane bending [5,6]. Based on obtained data it can be concluded that the role of various functional groups related to different secondary metabolites that exist in biomass filtrate of P. chrysogenum to reduce, capping, and stabilize Se-NPs.
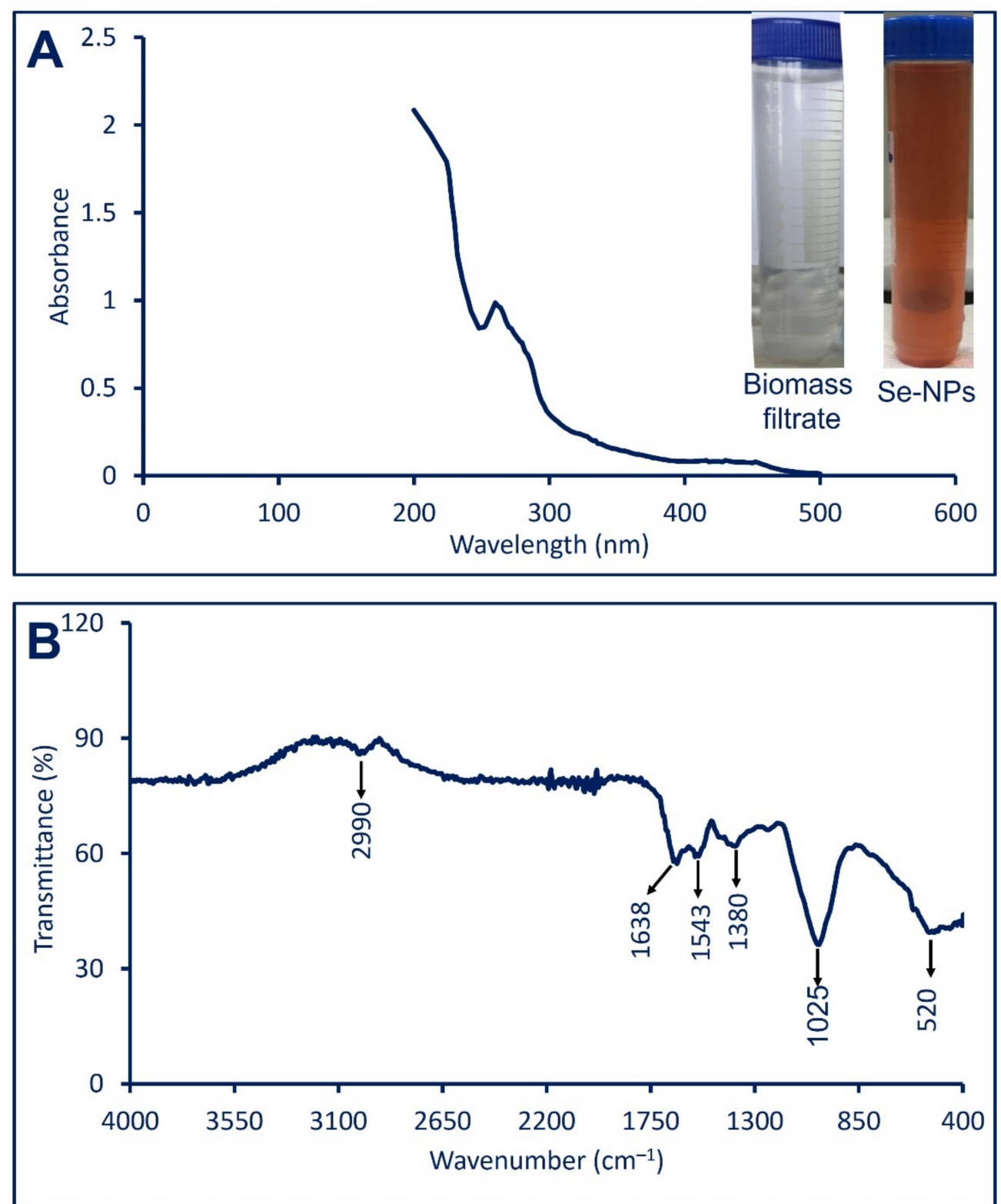

Figure 1. Characterization of Se-NPs fabricated by P. chrysogenum strain F9. (A) is shown the formation of ruby red color after mixing the biomass filtrate with sodium selenite and measuring their absorbance using UV-Vis spectroscopy; (B) is FT-IR (KBR methods) for green synthesized Se-NPs.

\subsubsection{Transmission Electron Microscopy (TEM)}

The morphological properties (shape and size) of myco-synthesized Se-NPs were analyzed by TEM. As shown in Figure 2A,B, the biomass filtrate of fungal strain F9 can fabricate spherical, homogenous with a modest aggregation of Se-NPs with size ranging between $3 \mathrm{~nm}$ to $15 \mathrm{~nm}$ with an average size of $7.3 \pm 3.7 \mathrm{~nm}$. The various biological activities of NPs, such as antimicrobial, cytotoxicity, larvicidal, and antioxidant activity, are dependent on NPs size, where smaller sizes have greater biological activity than large 
sizes [21]. For instance, the smaller sizes of Se-NPs fabricated by Pantoea agglomerans UC-32 showed higher biological activities (antioxidant and food additives) than those recorded by larger sizes [38]. Moreover, the antimicrobial activity of Se-NPs synthesized by garlic extract with a size range of 21-40 $\mathrm{nm}$ was greater than the activity recorded for higher sizes $(41-50 \mathrm{~nm})$ [39]. Therefore, we predict strong biological activities for Se-NPs synthesized in the current study.

The Energy dispersive X-ray (EDX) analysis is considered the most proper technique used for investigating the qualitative and quantitative chemical composition of the synthesized samples [40,41]. The EDX chart confirms the existence of Se at $1.38 \mathrm{KeV}$ with weight and atomic percentages of $38.52 \%$ and $32.22 \%$, respectively (Figure 2C) [42]. The maximum peaks located at 0.2 and $0.5 \mathrm{KeV}$ are associated with characteristic lines of carbon and oxygen, respectively, as reported previously [43]. The presence of $\mathrm{C}$ and $\mathrm{O}$ peaks in the EDX chart can be related to the capping and stabilizing agents attached to the Se-NPs surface originating from fungal biomass filtrate [44,45]. Compatible with our data, Sharma and co-authors reported that the carbon and oxygen peaks present in the EDX chart of Se-NPs fabricated by extract of Vitis vinifera are usually correlated with a stabilizing agent which maybe was alkyl chains [43].
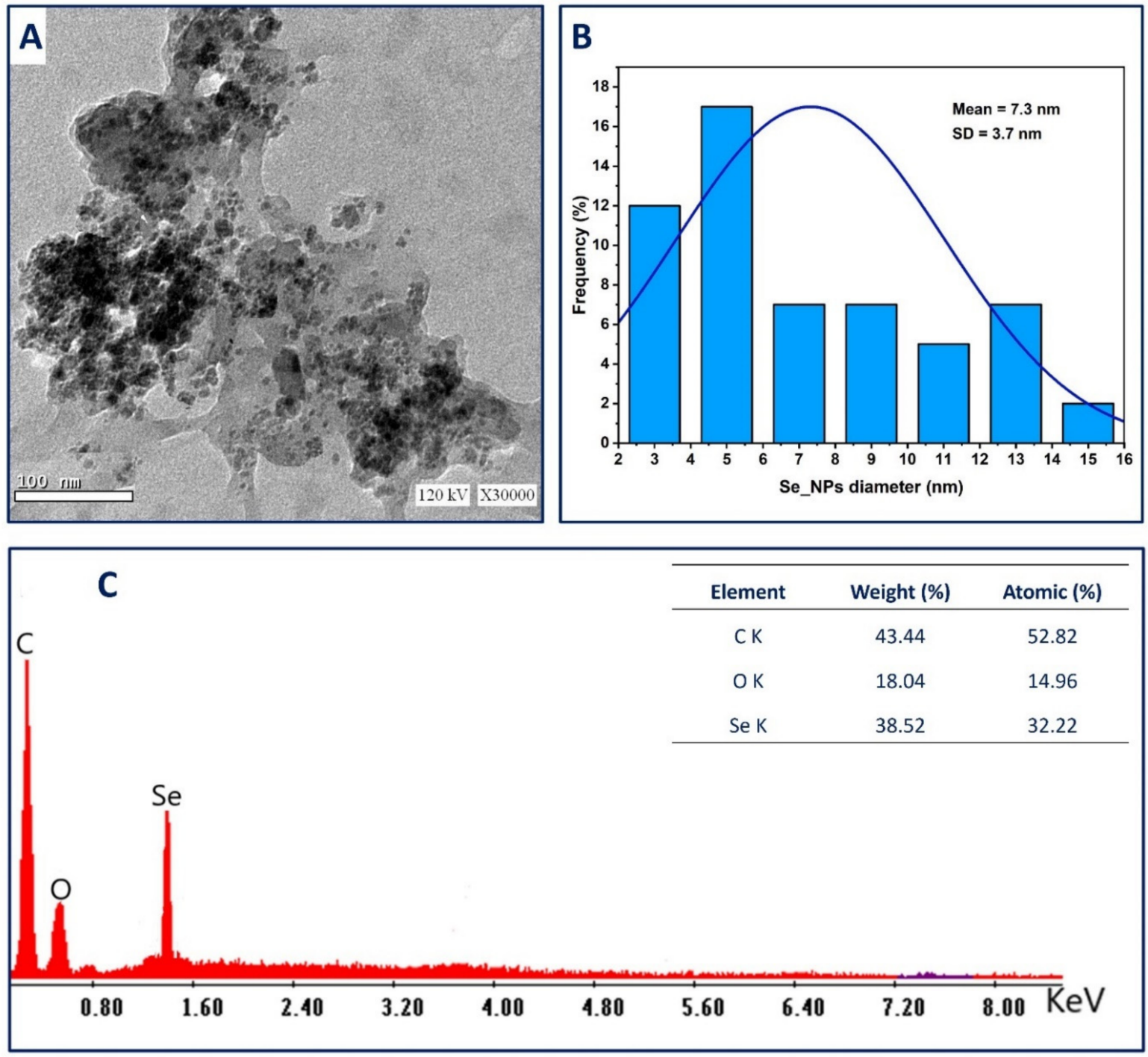

Figure 2. (A) is transmission electron microscopy (TEM); (B) is the size distribution based on TEM image, and (C) is the energy dispersive X-ray (EDX) analysis for fungal mediated green synthesize Se-NPs. 


\subsubsection{X-ray Diffraction Pattern (XRD)}

The nature (crystalline or amorphous) of fungal mediated biosynthesis of NPs was explored by XRD analysis [46]. Figure 3A showed a broader XRD pattern lacking any sharp Bragg's peak, which indicates the synthesized Se-NPs was an amorphous structure. This structure can be attributed to the array of selenium atoms in the form of irregular chains as reported previously [47]. Although the XRD pattern lacks any strong peaks, there are small peaks observed at $2 \theta$ values of $21.4^{\circ}, 28.9^{\circ}, 36.49^{\circ}$, and $44.8^{\circ}$ (Figure $3 \mathrm{~A}$ ). These data are matched with Rajkumar et al. [48], showing the successful formation of amorphous Se-NPs by Pseudomonas stutzeri strain MH191156 with observed small peaks in XRD pattern at $2 \theta$ values of $23^{\circ}, 26^{\circ}$, and $40^{\circ}$. The amorphous structure of green synthesized Se-NPs are reported previously, such as those synthesized by fruit extract of Emblica officinalis [47], Bacillus cereus [9], Alternaria alternata [49], and Anabaena variabilis strain NCCU-441 [50].
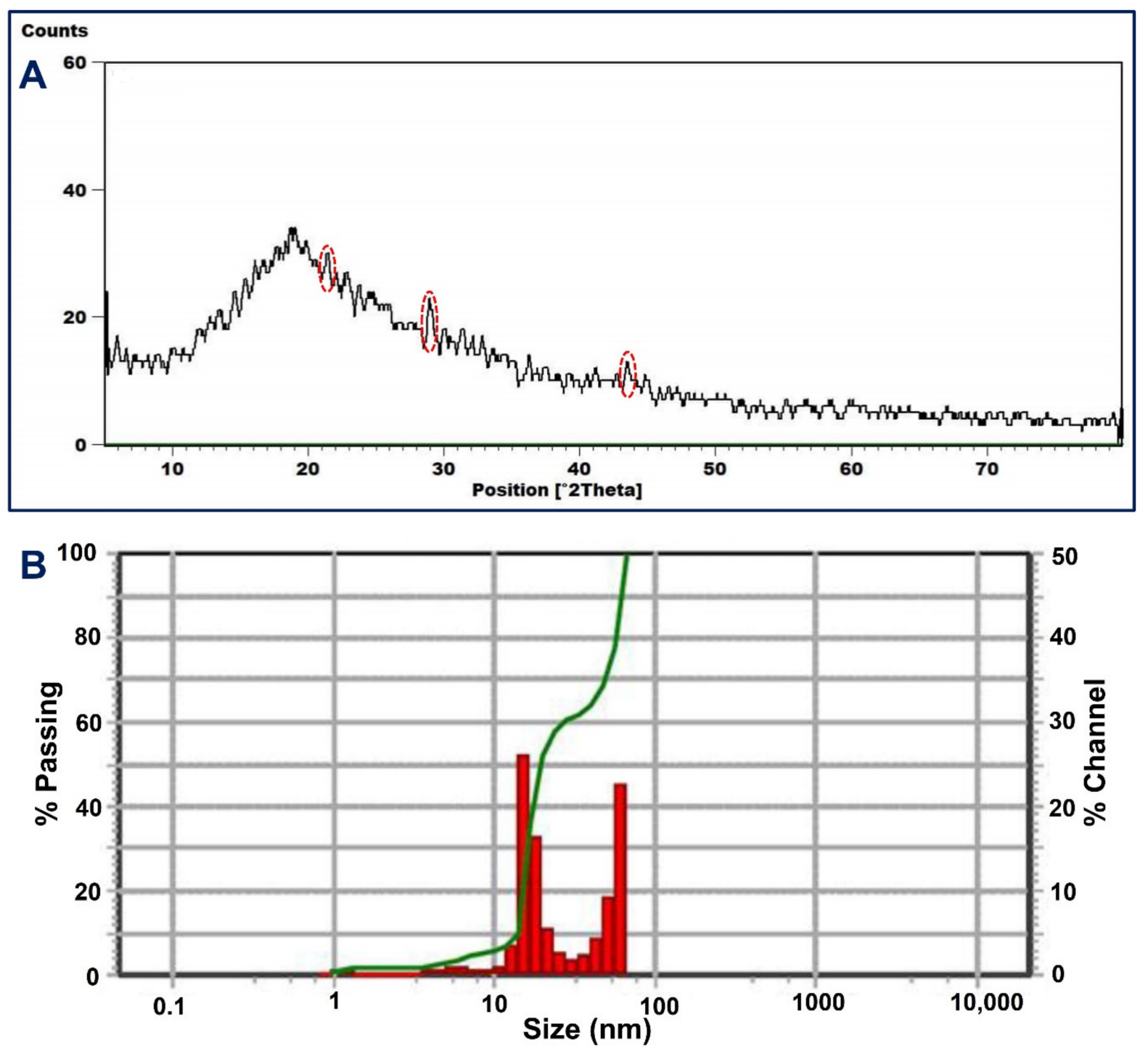

Figure 3. The X-ray diffraction (XRD) pattern (A) and the dynamic light scattering (DLS) (B) of the myco-synthesized Se-NPs.

\subsubsection{Dynamic Light Scattering (DLS)}

The size and homogeneity of synthesized NPs in colloidal solution were assessed using DLS analysis, in which the light beam reacts with suspended NPs in the solution [51,52]. 
The intensity of NPs in the colloidal solution affects the size obtained from DLS analysis. In the current study, the average Se-NPs size in the colloidal solution was $58.7 \mathrm{~nm}$ (2.3\% intensity) and $30.3 \mathrm{~nm}(97.7 \%$ intensity). As seen, the average size of Se-NPs obtained by DLS analysis is higher than those obtained by TEM analysis. This observation is because of various factors such as the accumulation of fungal metabolites (that serve as capping and stabilizing agents) on the surface of Se-NPs and which interfere with DLS measurement. Furthermore, the bigger Se-NPs size obtained by DLS can be related to the non-homogenous distribution in the colloidal solution and hydrodynamic particle residue $[51,53]$. The polydispersity index (PDI) that refers to homo- and heterogeneity of particles in the prepared colloidal solution can be recovered from DLS analysis. Data show that the PDI value for myco-synthesized Se-NPs was 0.03 , which refers to homogenous and less aggregate of nanoparticles. Similarly, the average size of Se-NPs synthesized by aqueous extract of Ceropegia bulbosa recovered from DLS analysis was $55.9 \mathrm{~nm}$, whereas the PDI value is 0.03 [54].

\subsection{The Efficacy of Se-NPs on the Growth Traits of the Sunflower Plant}

\subsubsection{Morphological Parameters}

The morphological parameters (shoot and root length, shoot and root fresh weight, and shoot and root dry weight) of sunflower due to foliar treatment with various SeNPs concentrations $(10,15,20$, and $25 \mathrm{ppm})$ are represented in Figure 4. The mentioned concentrations of Se-NPs significantly augmented length, fresh weight, and dry weight of shoots while insignificantly enhanced length, fresh weight, and dry weight of roots. The most effective treatment was 20 ppm Se-NPs, which significantly increased the shoot length and fresh and dry weight of the shoot with percentages of $56.7 \%, 96.6 \%$, and $96.6 \%$, respectively. Recent studies have revealed that Se-NPs can enhance plant growth $[10,55]$. Results from Ikram and co-authors revealed that foliar treatments of Se-NPs have a growthimproving impact on wheat plants by enhancing plant height, shoot length, root length, fresh and dry weight of shoot, fresh and dry weight of root, leaf area, and leaf number [12]. Additionally, the study of Hussein et al. [56] recorded some significant improvements in the morphological growth parameters (plant height, fresh and dry weights of shoot as well as fresh and dry weights of root) of groundnut cultivars as a result of foliar spray with selenium nanoparticles.

\subsubsection{Photosynthetic Pigments}

It is well known that photosynthetic pigments are an important factor to generate energy from light, in a process known as plant photosynthesis [57]. The obtained results in Figure 5 clarified that the application of Se-NPs (10, 15, 20, and $25 \mathrm{ppm})$ promoted the pigments of photosynthesis (chlorophylls and carotenoids). Selenium nanoparticles $(25 \mathrm{ppm}$ ) significantly enhanced chlorophyll- $a$ content by $99.4 \%$, whereas foliar treatment with Se-NPs at 15 ppm significantly increased chlorophyll- $b$ content by $41.4 \%$. On the other hand, Se-NPs at a concentration of $25 \mathrm{ppm}$ significantly promoted the content of total chlorophyll by $77.4 \%$, while Se-NPs at 20 ppm significantly boosted carotenoid contents by $167.4 \%$. Similarly, a recent study showed that the treatment of groundnut cultivars (NC and Giza 6) with Se-NPs at a concentration of $20 \mathrm{ppm}$ and $40 \mathrm{ppm}$ cause a significant increase in the chlorophyll and carotenoid contents [56]. Another study observed a promotion in the content of chlorophyll and carotenoids in cluster beans due to treatment by SeNPs [58]. It was documented that different metals in the nano-size can raise the content of chlorophyll, enhance the formation of pigments, and increase metabolic activities [55,59]. Besides the excellent biological characteristics and low toxicity of Se-NPs, it can be used as a stimulant for plant growth, improving the defense system, and increasing the amelioration of plants to different biotic and abiotic stresses. Therefore, Se-NPs have a significant role in improving the photosynthetic processes, increasing plant yield, and regulating the synthesis of reactive oxygen species (ROS) in plants [56,60]. 
(A) shoot length $(\mathrm{cm})$

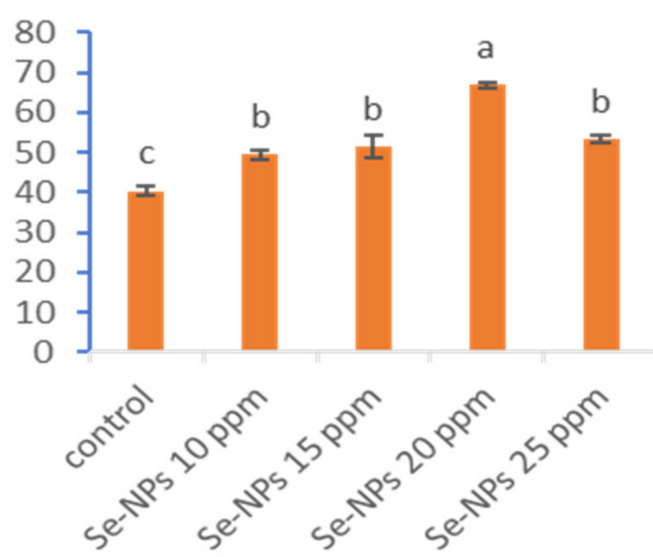

(C) shoot fresh weight (g)

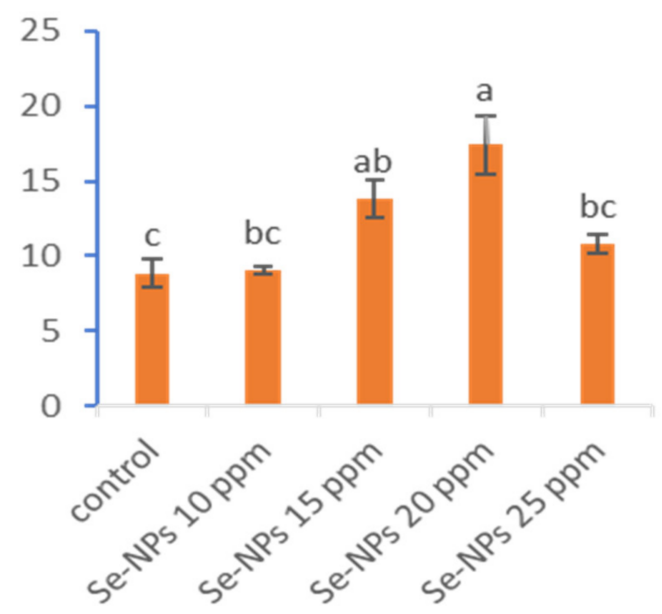

(E) root fresh weight (g)

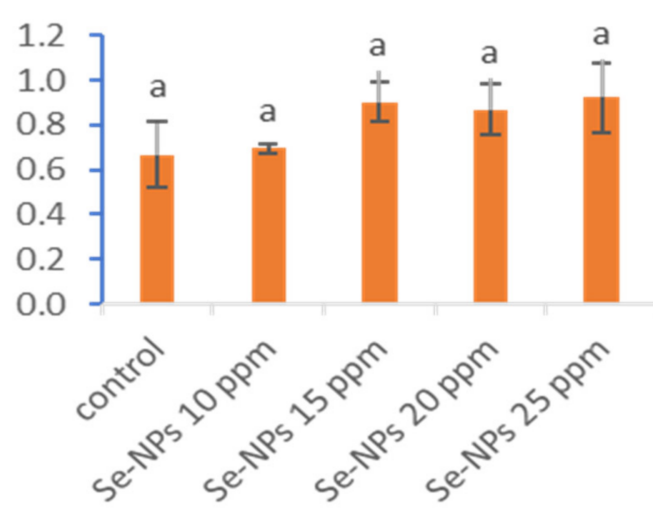

(B) root length $(\mathrm{cm})$

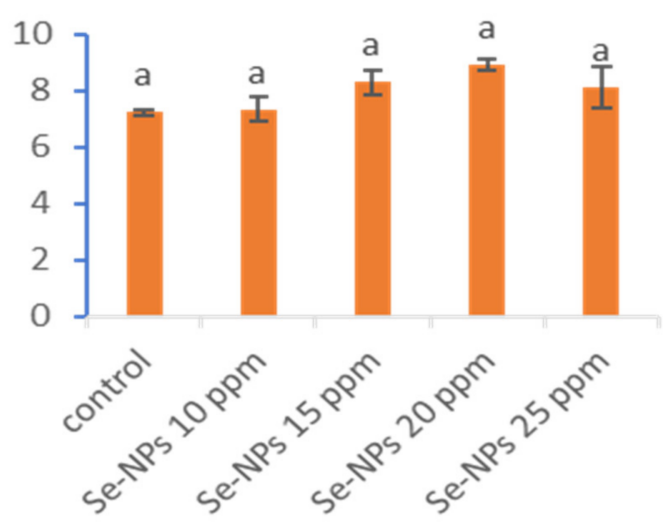

(D) shoot dry weight (g)

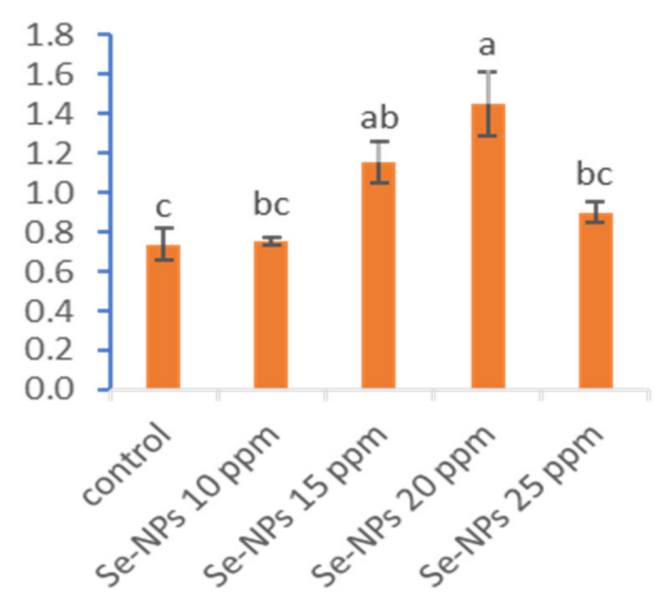

(F) root dry weight (g)

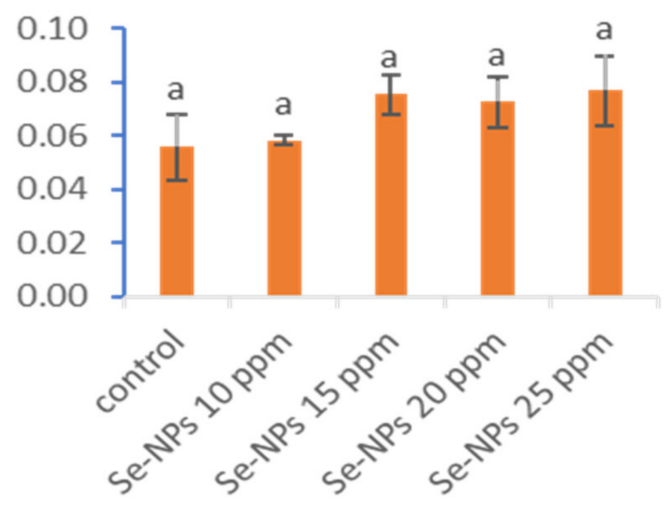

Figure 4. Effect of Se-NPs at different concentrations (10, 15, 20, and $25 \mathrm{ppm})$ on the length of the shoot (A) and root (B), shoot fresh (C) and dry (D) weight, root fresh (E), and dry weight $(\mathbf{F})$ of sunflower. Different letters on bars at the same test denote that mean values are significantly different $(p \leq 0.05)(\mathrm{n}=5)$. 
(A) chlorophyll a (mg/g FW)

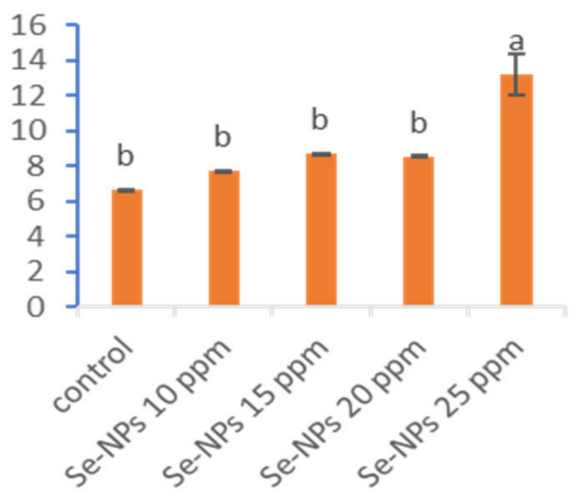

(C) chlorophyll a+b (mg/g FW)

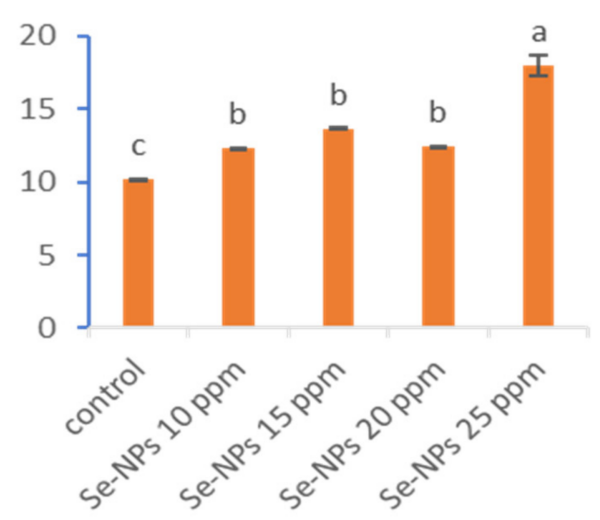

(B) chlorophyll b (mg/g FW)

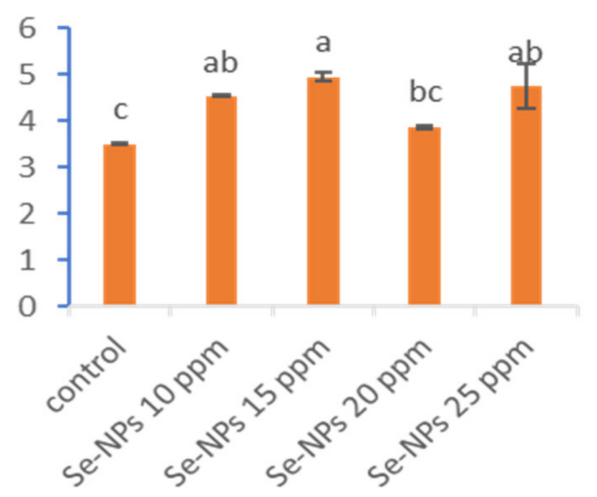

(D) carotenoids (mg/g FW)

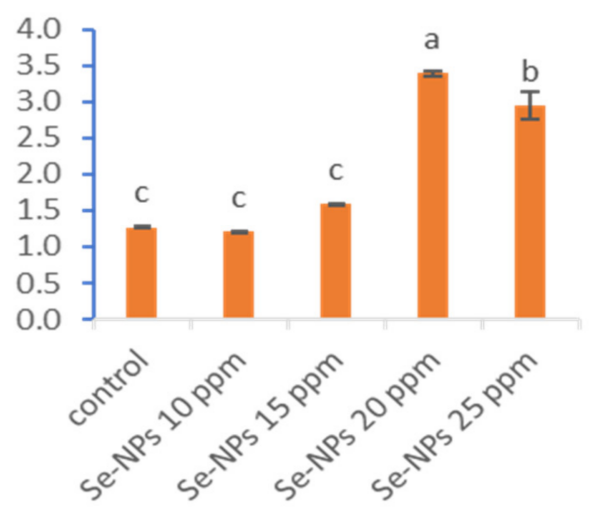

Figure 5. Effect of different concentrations of Se-NPs (10, 15, 20, and $25 \mathrm{ppm})$ on the contents of chlorophyll-a (A), chlorophyll-b (B), chlorophyll a+b (C), and carotenoids (D) of sunflower. Different letters on bars at the same test denote that mean values are significantly different $(p \leq 0.05)(n=3)$.

\subsubsection{Metabolic Parameters (Carbohydrates, Proteins, Free Proline, and Phenols)}

The impact of Se-NPs treatments at different concentrations (10, 15, 20, and 25 ppm) on the contents of carbohydrates, proteins, free proline, and phenols in sunflower plants was observed in Table 1.

Table 1. Effect of Se-NPs at different concentrations $(10,15,20$, and 25 ppm) on the contents of carbohydrates, proteins, free proline, and phenols of sunflower plants.

\begin{tabular}{ccccc}
\hline Treatments/ppm & Carbohydrates & Proteins & Free Proline & Phenols \\
\hline Control & $94.8 \pm 0.66^{\mathrm{d}}$ & $13 \pm 0.11^{\mathrm{d}}$ & $6.6 \pm 0.21^{\mathrm{c}}$ & $0.19 \pm 0.016^{\mathrm{c}}$ \\
Se-NPs 10 ppm & $190.8 \pm 2.17^{\mathrm{a}}$ & $15.1 \pm 0.06^{\mathrm{b}}$ & $9.5 \pm 0.19^{\mathrm{b}}$ & $0.28 \pm 0.026^{\mathrm{abc}}$ \\
Se-NPs 15 ppm & $186.5 \pm 1.89^{\mathrm{a}}$ & $17.5 \pm 0.03^{\mathrm{a}}$ & $9 \pm 0.2^{\mathrm{b}}$ & $0.30 \pm 0.017^{\mathrm{ab}}$ \\
Se-NPs 20 ppm & $162.5 \pm 0.93^{\mathrm{b}}$ & $15.4 \pm 0.13^{\mathrm{b}}$ & $9.7 \pm 0.34^{\mathrm{b}}$ & $0.25 \pm 0.018^{\mathrm{bc}}$ \\
Se-NPs 25 ppm & $147.2 \pm 0.67^{\mathrm{c}}$ & $13.7 \pm 0.10^{\mathrm{c}}$ & $10.9 \pm 0.16^{\mathrm{a}}$ & $0.37 \pm 0.031^{\mathrm{a}}$ \\
\hline
\end{tabular}

Values within the same column with different letters are significantly different $(p \leq 0.05)$, values are means $\pm \mathrm{SE}$ $(\mathrm{n}=3)$.

Regarding carbohydrate contents in sunflower plants, all the tested concentrations caused significant enhancements and the highest significant treatment was Se-NPs (10 ppm), which augmented carbohydrate contents by 101.2\%. Furthermore, the rest Se-NPs concentrations of 15, 20, and 25 ppm recorded significant increases by $96.7 \%, 71.4 \%$, and 55.3\%, respectively. In this respect, soluble sugar content in groundnut cultivars (NC, Gregory, 
and Giza 6) was promoted due to the foliar application with Se-NPs either at $20 \mathrm{ppm}$ or $40 \mathrm{ppm}[56]$.

With respect to protein content, all tested treatments have significantly increased the contents of protein in sunflower plants. Se-NPs (15 ppm) recorded the highest effective treatment that increased protein content by $34.6 \%$, while Se-NPs at 10, 20, and $25 \mathrm{ppm}$ caused significant increases reaching $16.4 \%, 18.4 \%$, and $5 \%$, respectively. It has been recorded in previous studies that the application of nanoparticles enhanced the content of protein $[61,62]$. It was previously documented that Se-NPs at $400 \mathrm{ppm}$ enhanced protein content in cluster bean plants more than those recorded by $500 \mathrm{ppm}$ [58]. Moreover, the foliar treatment for cowpea plants with selenium increased protein content either in normal or stressed conditions [63].

Free proline content in sunflower plants was significantly promoted due to the foliar application of Se-NPs at 10, 15, 20, and 25 ppm by $43.3 \%, 35.4 \%, 47.4 \%$, and $64.6 \%$, respectively. It has been reported that treating cluster bean plants with different concentrations of Se-NPs resulted in the induction of proline levels [58]. In a similar study, a significant increase in proline levels in the tomato plant was demonstrated due to the application of Se-NPs at a concentration of 3 and $10 \mathrm{mg} \mathrm{L}^{-1}$ [64].

Regarding phenolic compounds content, it was observed that the application of the tested treatments enhanced the content of phenolic compounds in sunflower plants. Se-NPs at 10 and $20 \mathrm{ppm}$ insignificantly increased phenolic compound contents, while Se-NPs at 15 and $25 \mathrm{ppm}$ recorded significant increases by $58.4 \%$ and $99.7 \%$, respectively. Interestingly, the foliar application with Se-NPs (20 and $40 \mathrm{ppm}$ ) led to a marked increase in total phenols content in groundnut cultivars (NC and Giza 6) [56]. Moreover, applications of Se-NPs enhances some responses in plants such as the content of phenolic compounds and total protein regarding healthy plants [14].

\subsubsection{Antioxidant Enzymes}

Figure 6 shows the antioxidant enzymes (catalase (CAT), peroxidase (POD), polyphenol oxidase (PPO), and superoxide dismutase (SOD)) of the sunflower plant due to foliar spray with different concentrations of Se-NPs. Data showed that the activities of antioxidant enzymes, CAT, POD, PPO, and SOD were significantly reduced as a result of the treatment with Se-NPs at 10, 15, 20, and $25 \mathrm{ppm}$. Our results are compatible with those obtained by Hussein et al. [56], who reported that the activities of some antioxidant enzymes such as peroxidase and catalase were strongly decreased in different cultivars of groundnut (Giza 6, Gerogry, and NC) that were treated with Se-NPs. The author suggested that the decrease in the antioxidant enzymes attributed to the critical role of selenium in detoxification that originates from oxidative stress. In a recent study, catalase activity was significantly decreased in the tested varieties of Brassica napus L. (Yangyou 9 and Zhongshuang 11) in response to the treatment with Se-NPs compared with the untreated plants, while SOD and POD activities were reduced as a result of Se-NPs application in comparison with stressed plants [65]. 
(A)

catalase $(\mu / g$ FW)

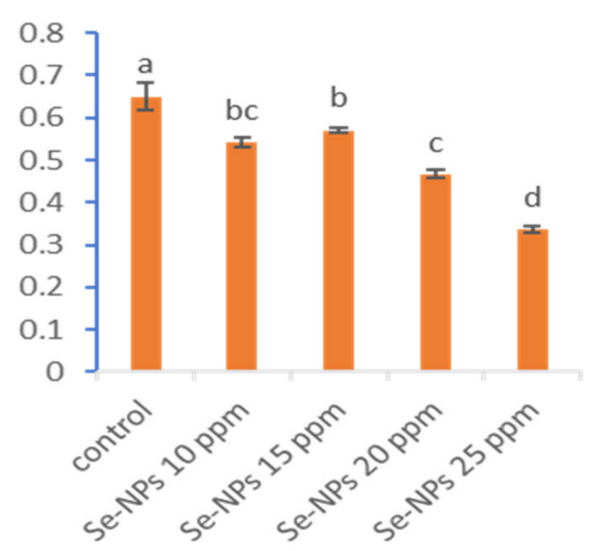

(C) polyphenol oxidase ( $\mu / \mathrm{g} \mathrm{FW})$

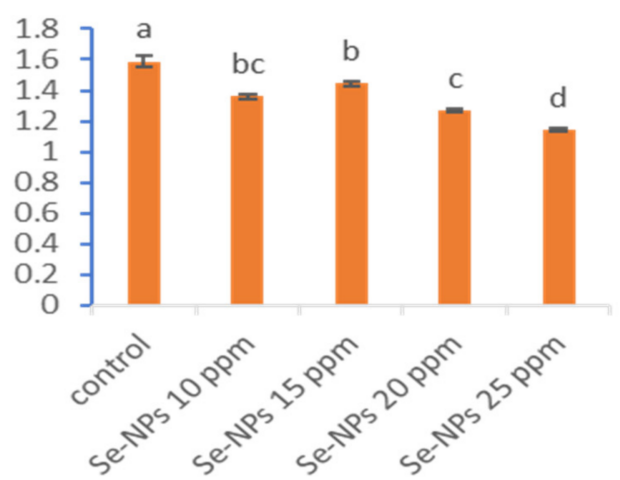

(B) peroxidase ( $\mu / \mathrm{g} \mathrm{FW)}$

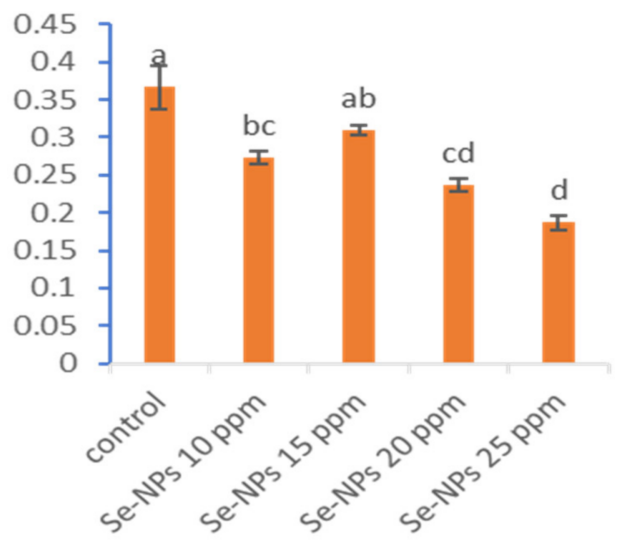

(D) superoxide dismutase $(\mu / \mathrm{g} \mathrm{FW})$

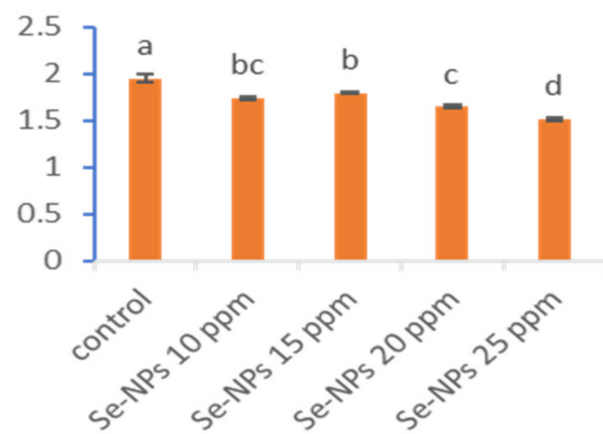

Figure 6. Effect of Se-NPs at different concentrations (10, 15, 20, and $25 \mathrm{ppm})$ on the activities of catalase (A), peroxidase (B), polyphenol oxidase (C), and superoxide dismutase (D) of sunflower plants. Different letters on bars at the same antioxidant enzyme denote that mean values are significantly different $(p \leq 0.05)(\mathrm{n}=3)$.

\subsection{Larvicidal Activity}

The efforts are increased to discover new active compounds that have activity against different medical and agricultural insects with low negative impacts on humans, animals, and the eco-system. In the past, researchers have proven the efficacy of different plant extracts and various essential oils as mosquitocidal agents, and used them as an alternative source for commercial compounds [66]. Recently, nano-formulation, especially those synthesized by green approaches, have become widely used in the treatment of various insects and pests [67]. The toxicity studies of biosynthesized nanoparticles are focused on the pests and insects that have medical importance over the crop insects. Therefore, the current research paper focused on the efficacy of green synthesized of Se-NPs on one of the most important crop insects, cutworm Agrotis ipsilon, as these NPs have a positive impact on the growth performance of the sunflower plant as mentioned above. To date, this is the first report to investigate the toxicity of Se-NPs on the A. ipsilon. Data represented in Table 2 reported that the activity of Se-NPs against different instar larvae was dose and time-dependent. This result is compatible with others who reported that the toxicity of biosynthesized CuO-NPs, MgO-NPs, and Ag-NPs was dose-dependent [68-70]. Data analysis showed that the highest mortality percentages were achieved at the highest Se-NPs concentration (25 ppm), which were $34.3 \pm 0.3 \%, 32.3 \pm 0.3 \%, 46.0 \pm 1.0 \%, 35.7 \pm 0.6 \%$, and $39.3 \pm 0.3 \%$ for 1 st to 5 th instar larvae after $24 \mathrm{~h}$. These mortality percentages were 
increased by increasing incubation time to reach $89.7 \pm 0.3 \%, 78.3 \pm 0.3 \%, 72.3 \pm 0.6 \%$, $63.7 \pm 0.3 \%$, and $68.7 \pm 0.3 \%$ for the same instar larvae after $72 \mathrm{~h}$ (Table 1 ). Mesbah and co-authors reported that the mortality percentages of $4^{\text {th }}$ instar larvae of $A$. ipsilon due to treatment with $0.1 \mathrm{~g}$ of silica nanoparticles (Si-NPs) was $63.3 \%$ after 12 days and increased to $73.3 \%$ mortality percentages by increasing the Si-NPs concentration to $0.5 \mathrm{~g}$ after the same time [71]. The difference between larvicidal efficacy of various nano-formulation can be attributed to the insect species, mode of action, application methods, developmental stages used, and incubation days after treatment [72]. Data analysis showed that the LC50 (that kills 50\% of larvae population) of Se-NPs was ranging between $2.9-4.2 \mathrm{ppm}$ for different instar larvae, whereas the LC90 (that kills $90 \%$ of larvae population) was ranging between 5.1-7.5 ppm. Similarly, the LC50 for nano-chlorantraniliprole and nano-thiocyclam against A. ipsilon were 0.015 and $4.46 \mathrm{mg} \mathrm{L}^{-1}$ which showed higher toxicity than bulk material [73].

The most accepted mechanism that explains the toxicity of nanoparticles against different insects was their efficacy in triggering oxidative stress in the arthropodal tissues [74] Moreover, the toxicity of NPs can be attributed to their efficacy to penetrate the insect exoskeleton and settle down onto the intracellular space. Then, the NPs bind to sulfur or phosphorus in proteins and nuclear materials leading to damage of different organelles and inhibiting enzyme functions. These lead to the disruption of selective permeability functions and proton motive force which lead to loss of cellular function and ultimately cell death $[75,76]$.

Table 2. Mortality percentages of different instar larvae of Agrotis ipsilon due to treatment by different concentrations (5, 10, 15, 20, and 25 ppm) of myco-synthesized Se-NPs.

\begin{tabular}{|c|c|c|c|c|c|c|c|c|c|c|c|c|c|c|c|}
\hline \multirow{3}{*}{$\begin{array}{c}\text { Se- } \\
\text { NPs } \\
\text { Conc. }\end{array}$} & \multicolumn{15}{|c|}{ Mortality Percentages $(\%) / \mathrm{h}$. } \\
\hline & \multicolumn{3}{|c|}{ 1st Instar Larvae } & \multicolumn{3}{|c|}{ 2nd Instar Larvae } & \multicolumn{3}{|c|}{ 3rd Instar Larvae } & \multicolumn{3}{|c|}{ 4th Instar Larvae } & \multicolumn{3}{|c|}{ 5th Instar Larvae } \\
\hline & $24 \mathrm{~h}$ & $48 \mathrm{~h}$ & $72 \mathrm{~h}$ & $24 \mathrm{~h}$ & $48 \mathrm{~h}$ & $72 \mathrm{~h}$ & $24 \mathrm{~h}$ & $48 \mathrm{~h}$ & $72 \mathrm{~h}$ & $24 \mathrm{~h}$ & $48 \mathrm{~h}$ & $72 \mathrm{~h}$ & $24 \mathrm{~h}$ & $48 \mathrm{~h}$ & $72 \mathrm{~h}$ \\
\hline 5 & 16.3 & 29.3 & 37.7 & 13.7 & 26.0 & 39.7 & 15.7 & 26.7 & 40.3 & 13.0 & 27.3 & 35.7 & 17.7 & 28.3 & 36.7 \\
\hline ppm & \pm 0.3 & & & & \pm 0 & & & & & \pm & & & & & \\
\hline 10 & 22.0 & 31 & & & 29 & 43.3 & 25.3 & 38.7 & 56.3 & 20.3 & 30.7 & 39.3 & 22.3 & 31.7 & 44.3 \\
\hline ppm & \pm 0.6 & \pm 0.3 & \pm & \pm 0.3 & \pm 0.4 & \pm 0.3 & \pm 0.8 & \pm 0.3 & \pm 0.6 & \pm 0.8 & \pm 0.9 & \pm 0.6 & \pm 0.3 & \pm 0.3 & \pm 0.3 \\
\hline 15 & 29.3 & 39.0 & 49.0 & 21.3 & 36.3 & 45.7 & 33.7 & 48.3 & 62.0 & 23.7 & 34.7 & 46.7 & 29.7 & 43.0 & 53.3 \\
\hline ppm & \pm 0.3 & \pm 0.0 & \pm 0.6 & \pm 0.3 & \pm 0.3 & \pm 0.6 & \pm 0.3 & \pm 0.3 & \pm 1.2 & \pm 0.9 & \pm 0.7 & \pm 0.3 & \pm 0.3 & \pm 0.6 & \pm 1.2 \\
\hline 20 & 37.3 & 49 & 61 & 28.3 & 40.3 & 57.7 & 39.7 & 56.3 & 69.7 & 29.7 & 37.3 & 56.7 & 31. & 43.0 & 62.7 \\
\hline ppm & \pm 0.3 & \pm 0.3 & \pm 0 & \pm 0. & \pm 0.3 & \pm 0.3 & \pm 0.3 & \pm 0.7 & \pm 0.3 & \pm 0.3 & \pm 0.3 & \pm 0 & \pm 0.3 & \pm 0.6 & \pm 0.3 \\
\hline 25 & 34.3 & 59.3 & 89.7 & 32.3 & 49.3 & 78.3 & 46.0 & 62.3 & 72.3 & 35.7 & 46.3 & 63.7 & 39.3 & 53.0 & 68.7 \\
\hline ppm & \pm 0.3 & \pm 0.3 & \pm 0.3 & \pm 0.3 & \pm 0.5 & \pm 0.3 & \pm 1.0 & \pm 1.2 & \pm 0.6 & \pm 0.6 & \pm 0.3 & \pm 0.3 & \pm 0.3 & \pm 1.5 & \pm 0.3 \\
\hline
\end{tabular}

\section{Materials and Methods}

\subsection{Myco-Synthesized Se-NPs}

\subsubsection{The Fungal Strain Used}

The fungal strain Penicillium chrysogenum F9 which was previously isolated from the historical manuscript was used as a biocatalyst for green synthesis of Se-NPs [24]. The fungal strain F9 was identified by morphological, cultural, and molecular-based amplification and sequencing of the internal transcribed spacer (ITS) gene. The obtained sequence of $P$. chrysogenum strain F9 was added in the genebank under the accession number MK452266.

\subsubsection{Myco-Synthesis of Se-NPs}

The fungal strain F9 was inoculated into potato dextrose broth (PDB) media and incubated for 7 days at $28 \pm 2{ }^{\circ} \mathrm{C}$. After an incubation period, the content of inoculated PDB was subjected to filtration by Whatman filter paper No.1 and then collected the filtrate which was further undergoing a centrifugation process at $8000 \mathrm{rpm}$ for $10 \mathrm{~min}$ to remove any cells and medium components. The supernatant (biomass filtrate or fungal cell-free filtrate) was used to reduce sodium selenite $\left(\mathrm{Na}_{2} \mathrm{SeO}_{3}\right)$ to form Se-NPs as follows: approximately $100 \mathrm{~mL}$ of collected biomass filtrate was mixed with $\mathrm{Na}_{2} \mathrm{SeO}_{3}$ to get a final 
concentration of $2 \mathrm{mM}$, mixed well, and incubated at $32 \pm 2{ }^{\circ} \mathrm{C}, \mathrm{pH}=7$, for $24 \mathrm{~h}$ under shaking condition (150 rpm). The formation of Se-NPs was checked by a color change of biomass filtrate from colorless to red color [28]. Finally, the as-formed Se-NPs were collected and subjected to oven-dried at $100{ }^{\circ} \mathrm{C}$ for $48 \mathrm{~h}$.

\subsection{Characterization of Myco-Synthesized MgO-NPs}

\subsubsection{UV-Vis Spectroscopy}

The myco-synthesized Se-NPs were examined visually through a color change of biomass filtrate during the incubation period. Moreover, the myco-synthesized Se-NPs were also checked by measuring the UV (JENWAY 6305 Spectrophotometer, $230 \mathrm{~V} / 50 \mathrm{~Hz}$, Staffordshire, UK) at wavelengths of 200-500 nm to detect the maximum surface plasmon resonance (SPR) which refer to intense absorption peak. The UV spectrum was recorded after $24 \mathrm{~h}$ of mixing fungal biomass filtrate and metal precursors to ensure the complete reduction. The biomass filtrate without $\mathrm{Na}_{2} \mathrm{SeO}_{3}$ served as a blank.

\subsubsection{Fourier Transform Infrared (FT-IR) Spectroscopy}

The role of fungal metabolites present in biomass filtrate in the reduction and stabilizing of Se-NPs was explored by Fourier transform infrared (FT-IR) analysis. The FT-IR spectra were analyzed using the Agilent system Cary 630 FT-IR model (Shimadzu, Tokyo, Japan). The analysis was achieved using the potassium bromide (KBr) method as follows: approximately $0.3 \mathrm{~g}$ of myco-synthesized Se-NPs was mixed with KBR under high pressure to form a disk that scanned at a range of $4000-400 \mathrm{~cm}^{-1}$.

\subsubsection{Transmission Electron Microscopy (TEM)}

The morphological properties of fungal-mediated synthesized Se-NPs were investigated by transmission electron microscopy (TEM, JEM-1230, JEOL, Tokyo, Japan, operating voltage $200 \mathrm{KV}$ ). A drop of Se-NPs solution was loaded on the TEM-grid (carbon-coated copper grid) and remains to complete adsorption. The excess amount of Se-NPs solution was removed by contacting the TEM-grid to blotting paper. The loaded grid was dried at room temperature before being added to the TEM-grid box for analysis [77]. The elemental contents of the Se-NPs sample were detected using energy dispersive X-ray (EDX).

\subsubsection{X-ray Diffraction (XRD) Patterns}

The crystalline or amorphous nature of myco-synthesized Se-NPs was assessed using X-ray analysis by X-ray diffractometer X'Pert Pro (Philips, Eindhoven, The Netherlands). The range of $2 \theta$ value was from $0^{\circ}$ to $80^{\circ}$. The $X$-ray source used during analysis was $\mathrm{Ni}$-filtered $\mathrm{Cu} \mathrm{Ka}$ radiation, while the voltage was $40 \mathrm{KV}$ and the current was $30 \mathrm{~mA}$.

\subsubsection{Dynamic Light Scattering (DLS)}

The distribution and size of green synthesized Se-NPs in colloidal solutions were studied using dynamic light scattering (DLS). The samples are suspended in distilled water and remain for one hour before being sonicated to ensure complete homogenization. The prepared colloidal solution was subjected to DLS measurement by a Zeta sizer nanoseries (Nano ZS), Malvern, UK. The DLS analysis gives information about the hetero- or homogeneity of NPs solutions by measuring the poly-dispersity index (PDI).

3.3. Effect of Different Se-NPs Concentrations on the Growth Performance of Helianthus annuus L. (sunflower) under Field Conditions

\subsubsection{Experimental Design}

In the current study, the Helianthus annuus L. seeds (var Sakha 53) were obtained from Agricultural Research Centre (ARC), Agriculture Ministry, Giza, Egypt. Uniform sunflower seeds were planted in natural loamy soil under field conditions in a plot $(12 \mathrm{~m} \times 15 \mathrm{~m}$ width $x$ length). The constituent of the loamy soil was as follows: sand $(95.2 \%)$, silt $(3.5 \%)$, clay $(1.4 \%), \mathrm{Na}\left(185.25 \mathrm{mg} \mathrm{kg}^{-1}\right), \mathrm{Ca}\left(25 \mathrm{mg} \mathrm{kg}^{-1}\right), \mathrm{K}\left(16.2 \mathrm{mg} \mathrm{kg}^{-1}\right), \mathrm{P}\left(24.3 \mathrm{mg} \mathrm{kg}^{-1}\right)$, and 
$\mathrm{Cl}\left(132.5 \mathrm{mg} \mathrm{kg}^{-1}\right)$. The field experiment was achieved under a completely randomized design containing five blocks, each block containing five plots for the following treatment: an untreated plot which served as a control, and a second, third, fourth, and fifth plot treated with 10, 15, 20, and 25 ppm of fungal mediated biosynthesized Se-NPs, respectively. The seeds were sown on one side of the ridge, $15 \mathrm{~cm}$ apart between the hills. The irrigation of growing plants was done whenever required [78]. The growing plants were sprayed with the above-mentioned treatments twice, the first and second sprays were applied at 15 and 25 days of planting, respectively. The five plants for each treatment were randomly collected for analysis when the plants were 30 days old.

\subsubsection{Morphological Characteristics}

After collecting the plant samples, the plant shoots were separated and the morphological parameters including shoot and root length, fresh weight of shoots and roots, and dry weight of shoots and roots after being oven dried at $80{ }^{\circ} \mathrm{C}$ were measured [79].

\subsubsection{Biochemical Analysis}

Photosynthetic Pigments

In this method, one gram from fresh leaves was ground and extracted in $100 \mathrm{~mL}$ acetone $(80 \%)$. The mixture was then filtered using Whatman filter paper (No. 1). The filtrate was transferred to a $100 \mathrm{~mL}$ volumetric flask and completed to get a volume of $100 \mathrm{~mL}$ with acetone (80\%). The optical density of the extract was measured at 470,649 , and $665 \mathrm{~nm}$. The following equations were used to calculate the contents of chlorophyll a, chlorophyll $b$, chlorophyll $(a+b)$, and carotenoids [80]:

$$
\begin{gathered}
\text { Chlorophyll a }(\mathrm{mg} / \mathrm{g} \text { tissue })=\{(11.63 \times \text { O.D.665 })-(2.39 \times \text { O.D.649 })\} \\
\text { Chlorophyll b }(\mathrm{mg} / \mathrm{g} \text { tissue })=\{(20.11 \times \text { O.D.649 })-(5.18 \times \text { O.D.665 })\} \\
\text { Chlorophyll } \mathrm{a}+\mathrm{b}(\mathrm{mg} / \mathrm{g} \text { tissue })=\{(6.45 \times \text { O.D.665 })+(17.72 \times \text { O.D.649 })\} \\
\text { Cartenoids }(\mathrm{mg} / \mathrm{g} \text { tissue })=\frac{\{1000 \times \text { O.D. } 470)-(1.82 \times \text { Chla })-(85.02 \times \text { Chlb })\}}{198}
\end{gathered}
$$

where A is the optical density; Chla is the chlorophyll-a; Chlb is the chlorophyll-b.

\section{Determination of Carbohydrate Content}

The carbohydrate contents were estimated as follows: one gram of the dried plant tissues was extracted in $5 \mathrm{~mL}$ of phenol solution $(2 \%)$ and $10 \mathrm{~mL}$ of trichloroacetic acid solution (30\%). After filtration, $2 \mathrm{~mL}$ from the extract was added to $4 \mathrm{~mL}$ of anthrone reagent $(0.2 \%$ anthrone/sulfuric acid $(95 \%))$. Finally, the green-blue color was measured, which appeared at $620 \mathrm{~nm}$ [81].

\section{Determination of Soluble Proteins}

The content of soluble proteins was assessed in the dried shoot of sunflower plants by the Lowery et al. [82] method. Approximately $0.1 \mathrm{~g}$ of the dried sample was homogenized with $5 \mathrm{~mL}$ of phenol solution $(2 \%)$ and $10 \mathrm{~mL}$ of distilled water. After that, one $\mathrm{mL}$ of the obtained extract was blended with $5 \mathrm{~mL}$ of alkaline reagent \{containing: $50 \mathrm{~mL}$ from solution $\mathrm{A}$ ( $50 \mathrm{~mL}$ of $2 \%$ sodium carbonate and dissolved in $0.1 \mathrm{~N}$ sodium hydroxide): $1 \mathrm{~mL}$ from solution B ( $0.5 \mathrm{~g}$ copper sulfate dissolved in $1.0 \%$ potassium sodium tartrate $)$ \} and homogenized thoroughly. Then, $0.5 \mathrm{~mL}$ of the diluted folin phenol reagent $(1: 3 \mathrm{v} / \mathrm{v})$ was added. After $30 \mathrm{~min}$, the developed color at $750 \mathrm{~nm}$ was measured.

\section{Determination of Free Proline}

The proline content in the dried shoot samples was assessed according to Bates et al. [83]. Briefly, a half gram of the dried sample was mixed with $10 \mathrm{~mL}$ of sulfosalicylic acid (3\%). The mixture was filtrated, then $2 \mathrm{~mL}$ of the filtrate was added to $2 \mathrm{~mL}$ of acid 
ninhydrin (prepared by warming $1.25 \mathrm{~g}$ ninhydrin with $30 \mathrm{~mL}$ acetic acid (glacial) and $20 \mathrm{~mL}$ of $6 \mathrm{M}$ phosphoric acid) and $2 \mathrm{~mL}$ of acetic acid (glacial) in a boiling water bath for one hour. After that, the reaction was kept in an ice bath followed by adding $4 \mathrm{~mL}$ of toluene to the previous mixture. At $520 \mathrm{~nm}$ the absorbance of the developed color was read. Proline contents in the sample were detected based on a prepared standard curve with known L-proline concentration

\section{Determination of Phenols}

The content of the total phenols in the dry shoot was determined as the following: the plant extract was added to a test tube and mixed with distilled $\mathrm{H}_{2} \mathrm{O}$ to get a final volume of $3.5 \mathrm{~mL}$. After that, the test tube content was oxidized by adding $250 \mu \mathrm{L}$ of Folin's-phenol reagent. After five minutes of incubation, the mixture was neutralized using $1.25 \mathrm{~mL}$ of $20 \% \mathrm{Na}_{2} \mathrm{CO}_{3}$. The absorbance of the formed color was measured at $725 \mathrm{~nm}$ after $40 \mathrm{~min}$ of the reaction against the blank solution. The content of phenols was calculated using the gallic acid standard curve [84].

\section{Extraction and Estimation of Antioxidant Enzymes}

The activities of antioxidant enzymes including peroxidase, catalase, superoxide dismutase, and polyphenol oxidase were detected from the young leaves and terminal buds. In this method, approximately two grams of the plant buds were ground with $10 \mathrm{~mL}$ of phosphate buffer $(0.1 \mathrm{M}, \mathrm{pH} 6.8)$, then the mixture was cooling centrifuged for $20 \mathrm{~min}$ at $20,000 \mathrm{rpm}$. The clear supernatant (containing the enzymes) was taken as the source of the enzyme

For catalase (CAT, EC 1.11.1.6) activity, $10 \mathrm{~mL}$ of the total mixture which consists of $40 \mu \mathrm{L}$ of the enzyme extract and mixed with $9.96 \mathrm{~mL}$ of oxygen water phosphate buffer at pH $7.0\left(0.16 \mathrm{~mL}\right.$ of $\mathrm{H}_{2} \mathrm{O}_{2}(30 \%)+100 \mathrm{~mL}$ of $50 \mathrm{mM}$ phosphate buffer). The activity of catalase enzyme was calculated through the change in $\mathrm{H}_{2} \mathrm{O}_{2}$ absorbance degree after $60 \mathrm{~s}$ using a UV-colorimetry at $250 \mathrm{~nm}$. Along with the experiment, the same procedure was achieved except that the enzyme extract with buffer solution and was replaced and used as a blank. The enzyme activity unit was estimated to be equivalent to the enzyme amount that reduced $50 \%$ of $\mathrm{H}_{2} \mathrm{O}_{2}$ at $25{ }^{\circ} \mathrm{C}$ within $60 \mathrm{~s}$ [85].

For peroxidase activity (POD, EC 1.11.1.7), the assay solution (5 mL) consisted of the following: $50 \mu \mathrm{M}$ pyrogallol $+50 \mu \mathrm{M} \mathrm{H}_{2} \mathrm{O}_{2}+125 \mu \mathrm{M}$ of phosphate buffer $(\mathrm{pH} 6.8)+1.0 \mathrm{~mL}$ of the $20 \times$ diluted enzyme extract. The formed color due to the amount of purpurogallin was measured at an absorbance of $420 \mathrm{~nm}$. The activity of the peroxidase enzyme was expressed as enzyme unit (EU)/mg protein [80].

The activity of polyphenol oxidase (PPO, 1.10.3.1) was assessed according to the method of Kar and Mishra [86]. Briefly, the solution assay consists of $100 \mu \mathrm{mol}$ of pyrogallols mixed with $125 \mu \mathrm{mol}$ of phosphate buffer ( $\mathrm{pH}$ 6.8) and $2 \mathrm{~mL}$ of crude enzyme extract and incubated at $25^{\circ} \mathrm{C}$ for $5 \mathrm{~min}$. At the end of the incubation period, the reaction was stopped by adding $1.0 \mathrm{~mL}$ of $5 \%$ of $\mathrm{H}_{2} \mathrm{SO}_{4}$. The control sample (blank) was carried out as mentioned above without enzyme extract. The developed color in treated and control solutions was measured at $430 \mathrm{~nm}$. The enzyme activity was calculated as the difference between two optical densities/g fresh weight/h.

Finally, the superoxide dismutase (SOD, EC 1.15.1.1) activity was examined according to methods described by Kong et al. [85]. In this method, $10 \mathrm{~mL}$ of assay solution consisting of: $3.6 \mathrm{~mL}$ of distilled $\mathrm{H}_{2} \mathrm{O}+5.5 \mathrm{~mL}$ of $50 \mathrm{mM}$ phosphate buffer $(\mathrm{pH} 7.8)+0.1 \mathrm{~mL}$ of enzyme extract $+0.8 \mathrm{~mL}$ of $3 \mathrm{mM}$ pyrogallol (dissolved in $10 \mathrm{mM} \mathrm{HCl}$ ) was used. The reduction percent of pyrogallol was measured at $325 \mathrm{~nm}$. The activity of SOD was measured as an $\mathrm{EU} \mathrm{mg} \mathrm{m}^{-1}$ protein required to inhibit $50 \%$ of the autoxidation of pyrogallol at $25^{\circ} \mathrm{C}$. 


\subsection{Larvicidal Bioassay}

\subsubsection{Insect Culture}

Larvae of Agrotis ipsilon were purchased from Agricultural Research Center, Dokki, Giza, Egypt. Larvae were reared on the artificial diet under optimum conditions which were: $25 \pm 1{ }^{\circ} \mathrm{C}$, relative humidity $(75 \pm 5 \%)$, and photoperiod of $16: 8 \mathrm{~h}$ light: dark [87]. The used artificial diet containing the following: $175 \mathrm{~g}$ of chickpea flour, $24 \mathrm{~g}$ of yeast, $1.5 \mathrm{~g}$ of methyl 1-4 hydroxybenzoate, $0.75 \mathrm{~g}$ of sorbic acid, $2.35 \mathrm{~g}$ of ascorbic acid, $6.0 \mathrm{~mL}$ of linseed oil, $0.8 \mathrm{~g}$ of streptomycin, $8.0 \mathrm{~g}$ of agar-agar, and dissolved in $700 \mathrm{~mL}$ of doubledistilled $\mathrm{H}_{2} \mathrm{O}$. Approximately twenty-one pairs of adult insects were added to the plastic jar $(15 \mathrm{~cm} \times 15 \mathrm{~cm} \times 30 \mathrm{~cm}$ length $\times$ width $\times$ height $)$ containing a cotton swab adsorbed with a honey solution $(10 \%)$ for feeding the moth. The plastic jar was covered with a muslin cloth to prevent the moths escaping. The oviposition was done on the hanging tissue paper in the plastic jar, after hatching, the yields were transferred to vials containing an artificial diet. The released $2 \mathrm{nd}, 3 \mathrm{rd}$, 4th, and 5 th instar larvae were collected for the next step. Five Se-NPs concentrations ( $5 \mathrm{ppm}, 10 \mathrm{ppm}, 15 \mathrm{ppm}, 20 \mathrm{ppm}$, and $25 \mathrm{ppm}$ ) were prepared and used as treatment, whereas water was used as a control.

\subsubsection{Bioassay}

Different slices of an artificial diet $\left(4 \mathrm{~mm}^{3}\right)$ were prepared and each one was immersed into a solution of various Se-NPs concentration separately and left to dry. The different instar larvae of Agrotis ipsilon remained without feeding for two hours, after that, twenty larvae from each instar were fed on treated slices for $24 \mathrm{~h}$., followed by adding non-treated diet slices as larvae needed.

The experiment was achieved in glass vials covered with wire-Gaz lids under the previous optimum conditions required for the growth of Agrotis ipsilon. The experiment was done in triplicate, and larval mortality percentages were calculated after $72 \mathrm{~h}$ of treatment using the following equation [88].

$$
\text { Mortality percentages }(\%)=\frac{\text { Number of dead insect }}{\text { Number of treated insect }} \times 100
$$

\subsection{Statistical Analysis}

Data in the current study were subjected to statistical analysis by SPSS v17 (SPSS Inc., Chicago, IL, USA). The analysis of variance (ANOVA) was used to estimate the efficacy of Se-NPs on the growth performance of sunflowers. A posteriori multiple comparisons were done using Tukey's range tests at $p<0.05$. All results are the means of three to five independent replicates, as specified above.

\section{Conclusions}

In the current study, Se-NPs were successfully fabricated by reducing Se ions by metabolites secreted by fungal strain Penicillium chrysogenum F9. The successful fabrication process was monitored by the change in biomass filtrate color from colorless to ruby red color after mixing with metal precursor $\left(\mathrm{Na}_{2} \mathrm{SeO}_{3}\right)$. The physicochemical characterization of myco-synthesized Se-NPs was achieved by UV-Vis spectroscopy, TEM, FT-IR, XRD, EDX, and DLS analyses. Data showed the formation of amorphous nature, spherical Se-NPs with sizes ranging between 3 to $15 \mathrm{~nm}$. Moreover, FT-IR exhibited the role of functional groups present in fungal biomass filtrate in reducing, capping, and stabilizing Se-NPs. The growth performance of sunflower, as well as the growth inhibition of cutworm Agrotis ipsilon due to Se-NPs treatment at different concentrations, were investigated. Analysis of variance showed that the growth of sunflower as indicated by morphological characters and biochemical analysis was enhanced due to treatment by different concentrations of Se-NPs. Moreover, the mortality of cutworm A. ipsilon was dependent on the time and concentration of Se-NPs. The highest mortality percentages were $89.7 \pm 0.3,78.3 \pm 0.3$, $72.3 \pm 0.6,63.7 \pm 0.3$, and $68.7 \pm 0.3$ for 1 st, $2 \mathrm{nd}, 3 \mathrm{rd}$, 4th, and 5th instar larvae, respectively, 
after $72 \mathrm{~h}$ of treatment with $25 \mathrm{ppm}$. This study provides a promising tool to enhance plant growth and control of agricultural insects by an eco-friendly, low-cost, and highly efficient approach.

Author Contributions: Conceptualization, M.A.A. (Mohamed A. Amin), M.A.I., A.A.B. and A.F.; methodology, M.A.A. (Mohamed A. Amin), M.A.I., A.A.B., M.A.A. (Mohamed A. Awad), M.F.H., M.F.A. and A.F; software, A.A.B., M.F.H., and A.F.; validation, M.A.A. (Mohamed A. Amin), M.A.I., A.A.B., M.A.A. (Mohamed A. Awad), M.F.H., M.F.A. and A.F.; formal analysis, M.A.A. (Mohamed A. Amin), M.A.I., A.A.B., M.A.A. (Mohamed A. Awad), M.F.H., M.F.A. and A.F.; investigation, M.A.A. (Mohamed A. Amin), M.A.I, A.A.B., M.A.A. (Mohamed A. Awad), M.F.H. and A.F.; resources, M.A.A. (Mohamed A. Amin), M.A.I., A.A.B., M.F.H., M.F.A. and A.F.; data curation, M.A.A. (Mohamed A. Amin), M.A.I., A.A.B., M.A.A. (Mohamed A. Awad), M.F.H., M.F.A. and A.F.; writing-original draft preparation, M.A.A. (Mohamed A. Amin), M.A.I., A.A.B., M.A.A. (Mohamed A. Awad), and A.F.; writing-review and editing, M.A.A. (Mohamed A. Amin), M.A.I., A.A.B., M.A.A. (Mohamed A. Awad), M.F.A., and A.F.; supervision, M.A.A. (Mohamed A. Amin), M.A.I., A.A.B., M.A.A. (Mohamed A. Awad) and A.F.; project administration, M.A.A. (Mohamed A. Amin), M.A.I., A.A.B., M.A.A. (Mohamed A. Awad), M.F.H., M.F.A. and A.F.; funding acquisition, M.F.A.; All authors have read and agreed to the published version of the manuscript.

Funding: This research received no external funding.

Institutional Review Board Statement: Not applicable.

Informed Consent Statement: Not applicable.

Data Availability Statement: The data presented in this study are available on request from the corresponding author.

Acknowledgments: The authors extend their appreciation to Taif University for funding the current work by Taif University Researchers Supporting Project number (TURSP-2020/111), Taif University, Taif, Saudi Arabia. Authors extend their appreciation to the Botany and Microbiology Department, Faculty of Science, Al-Azhar University for the financial support. Mohammed F. Hamza thanks the School of Nuclear Science and Technology, University of South China, Heng Yang, China, and Nuclear Materials Authority, El-Maadi, Cairo, Egypt for supporting and fruitful collaboration.

Conflicts of Interest: The authors declare no conflict of interest.

\section{References}

1. Mittal, D.; Kaur, G.; Singh, P.; Yadav, K.; Ali, S.A. Nanoparticle-Based Sustainable Agriculture and Food Science: Recent Advances and Future Outlook. Front. Nanotechnol. 2020, 2, 10. [CrossRef]

2. Alkahtani, M.D.F.; Fouda, A.; Attia, K.A.; Al-Otaibi, F.; Eid, A.M.; Ewais, E.E.; Hijri, M.; St-Arnaud, M.; Hassan, S.E.; Khan, N.; et al. Isolation and Characterization of Plant Growth Promoting Endophytic Bacteria from Desert Plants and Their Application as Bioinoculants for Sustainable Agriculture. Agronomy 2020, 10, 1325. [CrossRef]

3. Salem, S.S.; Mohamed, A.; El-Gamal, M.; Talat, M.; Fouda, A. Biological Decolorization and Degradation of Azo Dyes from Textile Wastewater Effluent by Aspergillus niger. Egypt. J. Chem. 2019, 62, 1799-1813.

4. Saada, N.S.; Abdel-Maksoud, G.; Abd El-Aziz, M.S.; Youssef, A.M. Green synthesis of silver nanoparticles, characterization, and use for sustainable preservation of historical parchment against microbial biodegradation. Biocatal. Agric. Biotechnol. 2021, 32, 101948. [CrossRef]

5. Leso, V.; Fontana, L.; Iavicoli, I. Biomedical nanotechnology: Occupational views. Nano Today 2019, 24, 10-14. [CrossRef]

6. Jeevanandam, J.; Chan, Y.S.; Danquah, M.K. Biosynthesis of Metal and Metal Oxide Nanoparticles. ChemBioEng Rev. 2016, 3, 55-67. [CrossRef]

7. $\quad$ Eid, A.M.; Fouda, A.; Niedbała, G.; Hassan, S.E.; Salem, S.S.; Abdo, A.M.; Hetta, H.F.; Shaheen, T.I. Endophytic Streptomyces laurentii Mediated Green Synthesis of Ag-NPs with Antibacterial and Anticancer Properties for Developing Functional Textile Fabric Properties. Antibiotics 2020, 9, 641. [CrossRef]

8. Lashin, I.; Fouda, A.; Gobouri, A.A.; Azab, E.; Mohammedsaleh, Z.M.; Makharita, R.R. Antimicrobial and In Vitro Cytotoxic Efficacy of Biogenic Silver Nanoparticles (Ag-NPs) Fabricated by Callus Extract of Solanum incanum L. Biomolecules 2021, 11, 341. [CrossRef]

9. Kora, A.J. Bacillus cereus, selenite-reducing bacterium from contaminated lake of an industrial area: A renewable nanofactory for the synthesis of selenium nanoparticles. Bioresour. Bioprocess. 2018, 5, 30. [CrossRef] 
10. El-Ramady, H.; Faizy, S.E.D.; Abdalla, N.; Taha, H.; Domokos-Szabolcsy, É.; Fari, M.; Elsakhawy, T.; Omara, A.E.; Shalaby, T.; Bayoumi, Y.; et al. Selenium and Nano-Selenium Biofortification for Human Health: Opportunities and Challenges. Soil Syst. 2020, 4, 57. [CrossRef]

11. Feng, R.; Wei, C.Y. Antioxidative mechanisms on selenium accumulation in Pteris vittata L. a potential selenium phytoremediation plant. Plant Soil Environ. 2012, 58, 105-110. [CrossRef]

12. Ikram, M.; Raja, N.I.; Javed, B.; Mashwani, Z.-U.-R.; Hussain, M.; Hussain, M.; Ehsan, M.; Rafique, N.; Malik, K.; Sultana, T.; et al. Foliar applications of bio-fabricated selenium nanoparticles to improve the growth of wheat plants under drought stress. Green Process. Synth. 2020, 9, 706-714. [CrossRef]

13. Zahedi, S.M.; Abdelrahman, M.; Hosseini, M.S.; Hoveizeh, N.F.; Tran, L.-S.P. Alleviation of the effect of salinity on growth and yield of strawberry by foliar spray of selenium-nanoparticles. Environ. Pollut. 2019, 253, 246-258. [CrossRef]

14. Zohra, E.; Ikram, M.; Omar, A.A.; Hussain, M.; Satti, S.H.; Raja, N.I.; Mashwani, Z.-U.-R.; Ehsan, M. Potential applications of biogenic selenium nanoparticles in alleviating biotic and abiotic stresses in plants: A comprehensive insight on the mechanistic approach and future perspectives. Green Process. Synth. 2021, 10, 456-475. [CrossRef]

15. Gupta, M.; Gupta, S. An Overview of Selenium Uptake, Metabolism, and Toxicity in Plants. Front. Plant Sci. 2017, 7, 2074. [CrossRef] [PubMed]

16. Molnár, Á.; Kolbert, Z.; Kéri, K.; Feigl, G.; Ördög, A.; Szőllősi, R.; Erdei, L. Selenite-induced nitro-oxidative stress processes in Arabidopsis thaliana and Brassica juncea. Ecotoxicol. Environ. Saf. 2018, 148, 664-674. [CrossRef] [PubMed]

17. Pal, D. Chapter 130-Sunflower (Helianthus annuus L.) Seeds in Health and Nutrition. In Nuts and Seeds in Health and Disease Prevention; Preedy, V.R., Watson, R.R., Patel, V.B., Eds.; Academic Press: San Diego, CA, USA, 2011; pp. $1097-1105$.

18. Mashwani, Z.-u.-R.; Bashir, T.; Zahara, K.; Haider, S.; Tabassum, S.; Mudrikah, M. Chemistry, Pharmacology and Ethnomedicinal Uses of Helianthus annuus (Sunflower): A Review. Pure Appl. Biol. 2015, 4, 226-235.

19. Giada, M.D.; Mancini-Filho, J. Antioxidant capacity of the striped sunflower (Helianthus annuus L.) seed extracts evaluated by three in vitro methods. Int. J. Food Sci. Nutr. 2009, 60, 395-401. [CrossRef]

20. Binning, R.R.; Coats, J.; Kong, X.; Hellmich, R.L. Susceptibility to Bt proteins is not required for Agrotis ipsilon aversion to Bt maize. Pest Manag. Sci. 2015, 71, 601-606. [CrossRef]

21. Salem, S.S.; Fouda, A. Green Synthesis of Metallic Nanoparticles and Their Prospective Biotechnological Applications: An Overview. Biol. Trace Elem. Res. 2021, 199, 344-370. [CrossRef] [PubMed]

22. Soliman, A.M.; Abdel-Latif, W.; Shehata, I.H.; Fouda, A.; Abdo, A.M.; Ahmed, Y.M. Green Approach to Overcome the Resistance Pattern of Candida spp. Using Biosynthesized Silver Nanoparticles Fabricated by Penicillium chrysogenum F9. Biol. Trace Elem. Res. 2021, 199, 800-811. [CrossRef] [PubMed]

23. Pohl, C.; Polli, F.; Schütze, T.; Viggiano, A.; Mózsik, L.; Jung, S.; de Vries, M.; Bovenberg, R.A.L.; Meyer, V.; Driessen, A.J.M. A Penicillium rubens platform strain for secondary metabolite production. Sci. Rep. 2020, 10, 7630. [CrossRef]

24. Fouda, A.; Abdel-Maksoud, G.; Abdel-Rahman, M.A.; Salem, S.S.; Hassan, S.E.-D.; El-Sadany, M.A.-H. Eco-friendly approach utilizing green synthesized nanoparticles for paper conservation against microbes involved in biodeterioration of archaeological manuscript. Int. Biodeterior. Biodegrad. 2019, 142, 160-169. [CrossRef]

25. Joshi, S.M.; De Britto, S.; Jogaiah, S.; Ito, S.-I. Mycogenic Selenium Nanoparticles as Potential New Generation Broad Spectrum Antifungal Molecules. Biomolecules 2019, 9, 419. [CrossRef]

26. Ramamurthy, C.; Sampath, K.S.; Arunkumar, P.; Kumar, M.S.; Sujatha, V.; Premkumar, K.; Thirunavukkarasu, C. Green synthesis and characterization of selenium nanoparticles and its augmented cytotoxicity with doxorubicin on cancer cells. Bioprocess Biosyst. Eng. 2013, 36, 1131-1139. [CrossRef] [PubMed]

27. Abbas, H.; Abou Baker, D. Biological Evaluation of Selenium Nanoparticles Biosynthesized by Fusarium semitectum as Antimicrobial and Anticancer Agents. Egypt. J. Chem. 2020, 63, 1119-1133. [CrossRef]

28. Salem, S.S.; Fouda, M.M.G.; Fouda, A.; Awad, M.A.; Al-Olayan, E.M.; Allam, A.A.; Shaheen, T.I. Antibacterial, Cytotoxicity and Larvicidal Activity of Green Synthesized Selenium Nanoparticles Using Penicillium corylophilum. J. Clust. Sci. 2021, 32, 351-361. [CrossRef]

29. Mishra, R.R.; Prajapati, S.; Das, J.; Dangar, T.K.; Das, N.; Thatoi, H. Reduction of selenite to red elemental selenium by moderately halotolerant Bacillus megaterium strains isolated from Bhitarkanika mangrove soil and characterization of reduced product. Chemosphere 2011, 84, 1231-1237. [CrossRef]

30. Zare, B.; Babaie, S.; Setayesh, N.; Shahverdi, A.R. Isolation and characterization of a fungus for extracellular synthesis of small selenium nanoparticles. Nanomed. J. 2013, 1, 13-19.

31. Jain, R.; Seder-Colomina, M.; Jordan, N.; Dessi, P.; Cosmidis, J.; van Hullebusch, E.D.; Weiss, S.; Farges, F.; Lens, P.N. Entrapped elemental selenium nanoparticles affect physicochemical properties of selenium fed activated sludge. J. Hazard. Mater. 2015, 295, 193-200. [CrossRef]

32. Salem, S.S.; El-Belely, E.F.; Niedbała, G.; Alnoman, M.M.; Hassan, S.E.; Eid, A.M.; Shaheen, T.I.; Elkelish, A.; Fouda, A. Bactericidal and In-Vitro Cytotoxic Efficacy of Silver Nanoparticles (Ag-NPs) Fabricated by Endophytic Actinomycetes and Their Use as Coating for the Textile Fabrics. Nanomaterials 2020, 10, 2082. [CrossRef]

33. Phanjom, P.; Ahmed, G. Biosynthesis of silver nanoparticles by Aspergillus oryzae (MTCC No. 1846) and its characterizations. Nanosci. Nanotechnol. 2015, 5, 14-21. 
34. Hamza, M.F.; Ahmed, F.Y.; El-Aassy, I.; Fouda, A.; Guibal, E. Groundwater Purification in a Polymetallic Mining Area (SW Sinai, Egypt) Using Functionalized Magnetic Chitosan Particles. Water Air Soil Pollut. 2018, 229, 360. [CrossRef]

35. Wei, Y.; Salih, K.A.M.; Lu, S.; Hamza, M.F.; Fujita, T.; Vincent, T.; Guibal, E. Amidoxime Functionalization of Algal/Polyethyleneimine Beads for the Sorption of Sr(II) from Aqueous Solutions. Molecules 2019, 24, 3893. [CrossRef] [PubMed]

36. Hamza, M.F.; Fouda, A.; Elwakeel, K.Z.; Wei, Y.; Guibal, E.; Hamad, N.A. Phosphorylation of Guar Gum/Magnetite/Chitosan Nanocomposites for Uranium (VI) Sorption and Antibacterial Applications. Molecules 2021, 26, 1920. [CrossRef]

37. Hamza, M.F.; Hamad, D.M.; Hamad, N.A.; Abdel-Rahman, A.A.H.; Fouda, A.; Wei, Y.; Guibal, E.; El-Etrawy, A.-A.S. Functionalization of magnetic chitosan microparticles for high-performance removal of chromate from aqueous solutions and tannery effluent. Chem. Eng. J. 2022, 428, 131775. [CrossRef]

38. Torres, S.K.; Campos, V.L.; León, C.G.; Rodríguez-Llamazares, S.M.; Rojas, S.M.; González, M.; Smith, C.; Mondaca, M.A. Biosynthesis of selenium nanoparticles by Pantoea agglomerans and their antioxidant activity. J. Nanoparticle Res. 2012, 14, 1236. [CrossRef]

39. Sribenjarat, P.; Jirakanjanakit, N.; Jirasripongpun, K. Selenium nanoparticles biosynthesized by garlic extract as antimicrobial agent. Sci. Eng. Health Stud. 2020, 22-31. [CrossRef]

40. Elfeky, A.S.; Salem, S.S.; Elzaref, A.S.; Owda, M.E.; Eladawy, H.A.; Saeed, A.M.; Awad, M.A.; Abou-Zeid, R.E.; Fouda, A. Multifunctional cellulose nanocrystal / metal oxide hybrid, photo-degradation, antibacterial and larvicidal activities. Carbohydr. Polym. 2020, 230, 115711. [CrossRef]

41. Fouda, A.; Abdel-Maksoud, G.; Saad, H.A.; Gobouri, A.A.; Mohammedsaleh, Z.M.; Abdel-Haleem El-Sadany, M. The Efficacy of Silver Nitrate $\left(\mathrm{AgNO}_{3}\right)$ as a Coating Agent to Protect Paper against High Deteriorating Microbes. Catalysts 2021, 11, 310. [CrossRef]

42. Dhanjal, S.; Cameotra, S.S. Aerobic biogenesis of selenium nanospheres by Bacillus cereus isolated from coalmine soil. Microb. Cell Factories 2010, 9, 52. [CrossRef]

43. Sharma, G.; Sharma, A.R.; Bhavesh, R.; Park, J.; Ganbold, B.; Nam, J.S.; Lee, S.S. Biomolecule-mediated synthesis of selenium nanoparticles using dried Vitis vinifera (raisin) extract. Molecules 2014, 19, 2761-2770. [CrossRef]

44. El-Belely, E.F.; Farag, M.M.S.; Said, H.A.; Amin, A.S.; Azab, E.; Gobouri, A.A.; Fouda, A. Green Synthesis of Zinc Oxide Nanoparticles (ZnO-NPs) Using Arthrospira platensis (Class: Cyanophyceae) and Evaluation of their Biomedical Activities. Nanomaterials 2021, 11, 95. [CrossRef]

45. Fouda, A.; Hassan, S.E.-D.; Saied, E.; Hamza, M.F. Photocatalytic degradation of real textile and tannery effluent using biosynthesized magnesium oxide nanoparticles (MgO-NPs), heavy metal adsorption, phytotoxicity, and antimicrobial activity. J. Environ. Chem. Eng. 2021, 9, 105346. [CrossRef]

46. Fouda, A.; Hassan, S.E.-D.; Saied, E.; Azab, M.S. An eco-friendly approach to textile and tannery wastewater treatment using maghemite nanoparticles ( $\gamma-\mathrm{Fe}_{2} \mathrm{O}_{3}$-NPs) fabricated by Penicillium expansum strain (K-w). J. Environ. Chem. Eng. 2021, 9, 104693. [CrossRef]

47. Gunti, L.; Dass, R.S.; Kalagatur, N.K. Phytofabrication of Selenium Nanoparticles From Emblica officinalis Fruit Extract and Exploring Its Biopotential Applications: Antioxidant, Antimicrobial, and Biocompatibility. Front. Microbiol. 2019, $10,931$. [CrossRef] [PubMed]

48. Rajkumar, K.; Mvs, S.; Koganti, S.; Burgula, S. Selenium Nanoparticles Synthesized Using Pseudomonas stutzeri (MH191156) Show Antiproliferative and Anti-angiogenic Activity Against Cervical Cancer Cells. Int. J. Nanomed. 2020, 15, 4523-4540. [CrossRef] [PubMed]

49. Sarkar, J.; Dey, P.; Saha, S.; Acharya, K. Mycosynthesis of selenium nanoparticles. Micro Nano Lett. 2011, 6, 599-602. [CrossRef]

50. Afzal, B.; Yasin, D.; Naaz, H.; Sami, N.; Zaki, A.; Rizvi, M.A.; Kumar, R.; Srivastava, P.; Fatma, T. Biomedical potential of Anabaena variabilis NCCU-441 based Selenium nanoparticles and their comparison with commercial nanoparticles. Sci. Rep. 2021, $11,13507$. [CrossRef] [PubMed]

51. Tomaszewska, E.; Soliwoda, K.; Kadziola, K.; Tkacz-Szczesna, B.; Celichowski, G.; Cichomski, M.; Szmaja, W.; Grobelny, J. Detection Limits of DLS and UV-Vis Spectroscopy in Characterization of Polydisperse Nanoparticles Colloids. J. Nanomater. 2013, 2013, 313081. [CrossRef]

52. Fouda, A.; Hassan, S.E.-D.; Abdel-Rahman, M.A.; Farag, M.M.S.; Shehal-deen, A.; Mohamed, A.A.; Alsharif, S.M.; Saied, E.; Moghanim, S.A.; Azab, M.S. Catalytic degradation of wastewater from the textile and tannery industries by green synthesized hematite $\left(\alpha-\mathrm{Fe}_{2} \mathrm{O}_{3}\right)$ and magnesium oxide $(\mathrm{MgO})$ nanoparticles. Curr. Res. Biotechnol. 2021, 3, 29-41. [CrossRef]

53. Shaheen, T.I.; Fouda, A. Green approach for one-pot synthesis of silver nanorod using cellulose nanocrystal and their cytotoxicity and antibacterial assessment. Int. J. Biol. Macromol. 2018, 106, 784-792. [CrossRef]

54. Cittrarasu, V.; Kaliannan, D.; Dharman, K.; Maluventhen, V.; Easwaran, M.; Liu, W.C.; Balasubramanian, B.; Arumugam, M. Green synthesis of selenium nanoparticles mediated from Ceropegia bulbosa Roxb extract and its cytotoxicity, antimicrobial, mosquitocidal and photocatalytic activities. Sci. Rep. 2021, 11, 1032. [CrossRef]

55. Siddiqui, S.A.; Blinov, A.V.; Serov, A.V.; Gvozdenko, A.A.; Kravtsov, A.A.; Nagdalian, A.A.; Raffa, V.V.; Maglakelidze, D.G.; Blinova, A.A.; Kobina, A.V.; et al. Effect of Selenium Nanoparticles on Germination of Hordéum Vulgáre Barley Seeds. Coatings 2021, 11, 862. [CrossRef]

56. Hussein, H.-A.A.; Darwesh, O.M.; Mekki, B.B. Environmentally friendly nano-selenium to improve antioxidant system and growth of groundnut cultivars under sandy soil conditions. Biocatal. Agric. Biotechnol. 2019, 18, 101080. [CrossRef] 
57. Zai, X.M.; Zhu, S.N.; Qin, P.; Wang, X.Y.; Che, L.; Luo, F.X. Effect of Glomus mosseae on chlorophyll content, chlorophyll fluorescence parameters, and chloroplast ultrastructure of beach plum (Prunus maritima) under NaCl stress. Photosynthetica $\mathbf{2 0 1 2}$ 50, 323-328. [CrossRef]

58. Ragavan, P.; Ananth, A.; Rajan, M. Impact of selenium nanoparticles on growth, biochemical characteristics and yield of cluster bean Cyamopsis tetragonoloba. Int. J. Environ. Agric. Biotechnol. 2017, 2, 238983. [CrossRef]

59. Badawy, A.A.; Abdelfattah, N.A.H.; Salem, S.S.; Awad, M.F.; Fouda, A. Efficacy Assessment of Biosynthesized Copper Oxide Nanoparticles (CuO-NPs) on Stored Grain Insects and Their Impacts on Morphological and Physiological Traits of Wheat (Triticum aestivum L.) Plant. Biology 2021, 10, 233. [CrossRef]

60. Morales-Espinoza, M.C.; Cadenas-Pliego, G.; Pérez-Alvarez, M.; Hernández-Fuentes, A.D.; Cabrera de la Fuente, M.; BenavidesMendoza, A.; Valdés-Reyna, J.; Juárez-Maldonado, A. Se Nanoparticles Induce Changes in the Growth, Antioxidant Responses, and Fruit Quality of Tomato Developed under NaCl Stress. Molecules 2019, 24, 3030. [CrossRef]

61. Ewais, E.A.; Ismail, M.A.; Badawy, A. Vegetative growth, photosynthetic pigments and yield of Phaseolus vulgaris (L.) plants in response to the application of biologically-synthesized zinc oxide nanoparticles and zinc sulfate. Al Azhar Bull. Sci. 2017, 9, 33-46.

62. Amin, M.A.; Badawy, A.A. Metabolic changes in common bean plants in response to zinc nanoparticles and zinc sulfate. Int. J. Innov. Sci. Eng. Technol. 2017, 4, 321-335.

63. Manaf, H.H. Beneficial effects of exogenous selenium, glycine betaine and seaweed extract on salt stressed cowpea plant. Ann. Agric. Sci. 2016, 61, 41-48. [CrossRef]

64. Neysanian, M.; Iranbakhsh, A.; Ahmadvand, R.; Oraghi Ardebili, Z.; Ebadi, M. Comparative efficacy of selenate and selenium nanoparticles for improving growth, productivity, fruit quality, and postharvest longevity through modifying nutrition, metabolism, and gene expression in tomato; potential benefits and risk assessment. PLoS ONE 2020, 15, e0244207. [CrossRef] [PubMed]

65. El-Badri, A.M.; Batool, M.; Wang, C.; Hashem, A.M.; Tabl, K.M.; Nishawy, E.; Kuai, J.; Zhou, G.; Wang, B. Selenium and zinc oxide nanoparticles modulate the molecular and morpho-physiological processes during seed germination of Brassica napus under salt stress. Ecotoxicol. Environ. Saf. 2021, 225, 112695. [CrossRef] [PubMed]

66. Karthi, S.; Uthirarajan, K.; Manohar, V.; Venkatesan, M.; Chinnaperumal, K.; Vasantha-Srinivasan, P.; Krutmuang, P. Larvicidal Enzyme Inhibition and Repellent Activity of Red Mangrove Rhizophora mucronata (Lam.) Leaf Extracts and Their Biomolecules Against Three Medically Challenging Arthropod Vectors. Molecules 2020, 25, 3844. [CrossRef]

67. Fouda, A.; Hassan, S.E.; Abdo, A.M.; El-Gamal, M.S. Antimicrobial, Antioxidant and Larvicidal Activities of Spherical Silver Nanoparticles Synthesized by Endophytic Streptomyces spp. Biol. Trace Elem. Res. 2020, 195, 707-724. [CrossRef]

68. Marimuthu, S.; Rahuman, A.A.; Rajakumar, G.; Santhoshkumar, T.; Kirthi, A.V.; Jayaseelan, C.; Bagavan, A.; Zahir, A.A.; Elango, G.; Kamaraj, C. Evaluation of green synthesized silver nanoparticles against parasites. Parasitol. Res. 2011, 108, 1541-1549. [CrossRef] [PubMed]

69. Hassan, S.E.; Fouda, A.; Radwan, A.A.; Salem, S.S.; Barghoth, M.G.; Awad, M.A.; Abdo, A.M.; El-Gamal, M.S. Endophytic actinomycetes Streptomyces spp mediated biosynthesis of copper oxide nanoparticles as a promising tool for biotechnological applications. J. Biol. Inorg. Chem. 2019, 24, 377-393. [CrossRef]

70. Hassan, S.E.; Fouda, A.; Saied, E.; Farag, M.M.S.; Eid, A.M.; Barghoth, M.G.; Awad, M.A.; Hamza, M.F.; Awad, M.F. Rhizopus oryzaeMediated Green Synthesis of Magnesium Oxide Nanoparticles (MgO-NPs): A Promising Tool for Antimicrobial, Mosquitocidal Action, and Tanning Effluent Treatment. J. Fungi 2021, 7, 372. [CrossRef]

71. Mesbah, H.; Kordy, A.; Tayeb, E.; Mourad, A.; El-Shershaby, M.; El-Wakel, N. Silica Nano Particles Bait Against the Black Cutworm, Agrotis ipsilon (Hufn.). J. Nucl. Technol. Appl. Sci. 2020, 8, 153-162. [CrossRef]

72. Madhuban, G.; Rajesh, K.; Arunava, G. Nano-pesticides-A recent approach for pest control. J. Plant Prot. Sci. $2012,4,1-7$.

73. Awad, M.; Ibrahim, E.-D.S.; Osman, E.I.; Elmenofy, W.H.; Mahmoud, A.W.M.; Atia, M.A.M.; Moustafa, M.A.M. Nano-Insecticides Against the Black Cutworm Agrotis ipsilon (Lepidoptera: Noctuidae): Toxicity, Development, Enzyme activity, and DNA Mutagenicity. bioRxiv 2021. [CrossRef]

74. Mao, B.-H.; Chen, Z.-Y.; Wang, Y.-J.; Yan, S.-J. Silver nanoparticles have lethal and sublethal adverse effects on development and longevity by inducing ROS-mediated stress responses. Sci. Rep. 2018, 8, 2445. [CrossRef]

75. Benelli, G. Green synthesized nanoparticles in the fight against mosquito-borne diseases and cancer-a brief review. Enzym. Microb. Technol. 2016, 95, 58-68. [CrossRef]

76. Hassan, S.E.L.D.; Salem, S.S.; Fouda, A.; Awad, M.A.; El-Gamal, M.S.; Abdo, A.M. New approach for antimicrobial activity and bio-control of various pathogens by biosynthesized copper nanoparticles using endophytic actinomycetes. J. Radiat. Res. Appl. Sci. 2018, 11, 262-270. [CrossRef]

77. Shaheen, T.I.; Fouda, A.; Salem, S.S. Integration of Cotton Fabrics with Biosynthesized CuO Nanoparticles for Bactericidal Activity in the Terms of Their Cytotoxicity Assessment. Ind. Eng. Chem. Res. 2021, 60, 1553-1563. [CrossRef]

78. Ismail, M.A.; Amin, M.A.; Eid, A.M.; Hassan, S.E.; Mahgoub, H.A.M.; Lashin, I.; Abdelwahab, A.T.; Azab, E.; Gobouri, A.A.; Elkelish, A.; et al. Comparative Study between Exogenously Applied Plant Growth Hormones versus Metabolites of Microbial Endophytes as Plant Growth-Promoting for Phaseolus vulgaris L. Cells 2021, 10, 1059. [CrossRef]

79. Fouda, A.; Eid, A.M.; Elsaied, A.; El-Belely, E.F.; Barghoth, M.G.; Azab, E.; Gobouri, A.A.; Hassan, S.E. Plant Growth-Promoting Endophytic Bacterial Community Inhabiting the Leaves of Pulicaria incisa (Lam.) DC Inherent to Arid Regions. Plants 2021, 10, 76. [CrossRef] [PubMed] 
80. Mahgoub, H.A.M.; Fouda, A.; Eid, A.M.; Ewais, E.E.-D.; Hassan, S.E.-D. Biotechnological application of plant growth-promoting endophytic bacteria isolated from halophytic plants to ameliorate salinity tolerance of Vicia faba L. Plant Biotechnol. Rep. 2021, 15, 819-843. [CrossRef]

81. Umbreit, W.W.; Burris, R.H.; Stauffer, J.F. Manometric Techniques: A Manual Describing Methods Applicable to the Study of Tissue Metabolism; Burgess Publishing Company: Minneapolis, MN, USA, 1964.

82. Lowry, O.H.; Rosebrough, N.J.; Farr, A.L.; Randall, R.J. Protein measurement with the Folin phenol reagent. J. Biol. Chem. 1951, 193, 265-275. [CrossRef]

83. Bates, L.S.; Waldren, R.P.; Teare, I.D. Rapid determination of free proline for water-stress studies. Plant Soil 1973, 39, 205-207. [CrossRef]

84. Dai, G.; Andary, C.; Cosson-Mondolot, L.; Boubals, D. Polyphenols and Resistance of Grapevines to Downy Mildew. In Proceedings of the International Symposium on Natural Phenols in Plant Resistance, Acta Horticulturae, Weihenstephan, Germany, 13-17 September 1993; Volume 381, pp. 763-766.

85. Kong, F.; Hu, W.M.; Chao, S.; Sang, W.; Wang, L.S. Physiological responses of the lichen Xanthoparmelia mexicana to oxidative stress of $\mathrm{SO}_{2}$. Environ. Exp. Bot. 1999, 42, 201-209. [CrossRef]

86. Kar, M.; Mishra, D. Catalase, Peroxidase, and Polyphenoloxidase Activities during Rice Leaf Senescence. Plant Physiol. 1976, 57, 315-319. [CrossRef] [PubMed]

87. Xu, C.; Zhang, Z.; Cui, K.; Zhao, Y.; Han, J.; Liu, F.; Mu, W. Effects of Sublethal Concentrations of Cyantraniliprole on the Development, Fecundity and Nutritional Physiology of the Black Cutworm Agrotis ipsilon (Lepidoptera: Noctuidae). PLoS ONE 2016, 11, e0156555. [CrossRef] [PubMed]

88. Fouda, A.; Awad, M.A.; Eid, A.M.; Saied, E.; Barghoth, M.G.; Hamza, M.F.; Awad, M.F.; Abdelbary, S.; Hassan, S.E. An EcoFriendly Approach to the Control of Pathogenic Microbes and Anopheles stephensi Malarial Vector Using Magnesium Oxide Nanoparticles (Mg-NPs) Fabricated by Penicillium chrysogenum. Int. J. Mol. Sci. 2021, 22, 5096. [CrossRef] [PubMed] 